\title{
XVI. YÜZYIL SONLARINDA SAMTSKHE-CAVAKHETİ KÖYLERINIIN SOSYAL VE EKONOMIK YAPISI: SAKUNETİ KÖYÜ ÖRNEĞİ
}

\author{
THE SOCIAL AND ECONOMIC STRUCTURE OF SAMTSHKE-JAVAKHETİ \\ VILLAGES AT THE END OF XVI CENTURY: THE SAMPLE OF SAKUNETI \\ VILLAGE
}
СОЦИАЛЬНАЯ И ЭКОНОМИЧЕСКАЯ СТРУКТУРА СЕЛ САМЦХЕ-ДЖАВАХЕТИ В КОНЦЕ 16-ГО ВЕКА: НА ПРИМЕРЕ СЕЛА САКУНЕТИ

\author{
Iasha BEKADZE*
}

\section{ÖZ}

Sakuneti köyü 312 yıl (1266-1578) ve Samtskhe-Saatabago ise 250 yıl boyunca (15791829) Osmanlı Devleti'nin Çıldır Eyâleti Ahıska Sancağı Azğur Nahiyesi'ne bağlı bulunmaktaydı. Günümüzde bu köy Gürcistân Cumhuriyeti Samtskhe-Cavakheti Bölgesi Akhaltsikh Belediyesi sınırları içerisindedir. Bu çalışmada, Sakuneti'nin etimolojisi, kısa tarihi, coğrafi konumu, nüfusu ve halkın dini mensubiyeti hakkında bilgiler verildikten sonra Hicrî 1003 (1595) tarihli TTD ve "Defter-i Mufassal Vilâyet-i Gürcistân" tahrir defteri ışığında köyün ziraî yapısı ve köylülerin geçim durumları araştırılarak bazı tespitler yapılmıştır. Bu tarihte 17 haneli Sakuneti köyünün yaklaşık nüfusu 136'dır. Nüfusun çoğu gayrimüslimlerden ibarettir. Defter kayıtlarından yararlanarak, köy halkının bu dönemde geçiminin tarım ve hayvancılıkla sağladığını söylemek mümkündür. Tarımsal ürünler olarak buğday ve arpa ön sıraya çıkarken, bağcılık ve bahçecilik de yaygın olmuştur. Köyde küçükbaş hayvan ve arıcılık yetiştiriliciği tahrir defterinde görülmektedir. Ayrıca köyde teknik işletmelerden olan değirmenler de faaliyet göstermektedir.

Anahtar Sözcükler: Samtskhe-Cavakheti, Akhaltsikh Belediyesi, Çıldır Eyâleti, Ahıska Sancağı, Azğur Nahiyesi, Sakuneti.

\section{ABSTRACT}

The village of Sakuneti was connected to the Samtskhe Saatabago for 312 years (12661578) and 250 years (1579-1829) to the Childir Province of Atskhuri region of Ottoman state. Today this village is within the borders of Akhaltsikhe Municipality, the Republic of Georgia. In this research, we made some determinations about the agrarian structure of the village based on Ottoman State recordings called "Defter-i Mufassal Vilâyet-i Gürcistân" dated by 1595 TTD and 1003 year by Hijri Calendar. The etymology, brief history, geographic possition, and religious affilations of Sakuneti village are also mentioned. At this date, the population of Sakuneti Village consisting of 17 families was 136 people. Most of them were not Muslims. According the recordings, it is possible to say that the means of existance of the villagers depended on farming and agriculture. Wheat and barley were the most common means of income, and viniculture and horticulture was common. According

*Bağımsız Araştırmacı, dryasar5@hotmail.com 
to the recordings, there was apiculture and ovine breeding. In addition, mills were operating in the village, too.

Key Words: Samtskhe-Javakheti, Akhaltsikhe Municipality, Childir Province, Ahiska Sanjak, Atskhuri Region, Sakuneti

\section{АННОТАЦИЯ}

Сакунети в течение 312 лет (1266-1578) входило в состав Самцхе-Саатабаго и 250 лет (1579-1829) в район Ацкури Ахалцихской ливы Османского государства. В настоящее время оно находится на территории Ахалцихского муниципалитета региона Самцхе-Джавахети Республики Грузия. В этом исследовании даны сведения об этимологии села Сакунети, краткой его истории, географическом положении, населении и его религиозной принадлежности. Согласно «Пространному реестру Гюрджистанского вилаета» и TTD (подробному земельному кадастре), датированных хиджры 1003 (1595) была выявлена сельскохозяйственная структура села и определены некоторые моменты условий жизни крестьян. В 1595 году в Сакунети было 17 дворов, где численность населения составляла приблизительно 136 человек. Большинством населения были христиане. Согласно реестру, можно сделать вывод, что в этот период, средством существования населения села были занятия сельским хозяйством и животноводством. На первом месте из сельскохозяйственных культур были пшеница и ячмень. Также были распространены виноградарство и садоводство. Согласно данным реестра в селе занимались разведением мелкого рогатого скота и пчеловодством. Кроме того, можно отметить, что в селе работали технические предприятия - мельницы.

КЛЮЧЕВЫЕ СЛОВА: Самцхе-Джавахети, Ахалцихский мунициполитет, Чилдирский эялет, Ахалцихский санджак, Ацкурский район, Сакунети

\section{Giriş}

Samtskhe-Cavakheti, Gürcistan'ın güneyinde olup üç tarihi bölgeden; Samtskhe, Cavakheti ve Tori'den teşkil olunmuştur. Samtskhe, Akhaltsikhe, Adigeni ve Aspinza'nın Khertvis'e kadar olan kısmını, Cavakheti, Akhalkalaki, Ninosminda ve Aspinza'nın Khertvis sonrası olan kısmını, Tori ise Borcomi Belediyesi'ni içermektedir. Bölgenin toplam alanı $6.421 \mathrm{~km}^{2}$ olup idari merkezi Akhaltsikhe şehridir. Samtskhe-Cavakheti güneyde Türkiye ve Ermenistan'la komşu olup kuzeyinde Guriya, İmereti ve Şida Kartli, doğusunda Kvemo Kartli, batısında Acara bulunmaktadır. Bölgenin içerisinden Güney Kafkasya'nın en büyük nehri olan Kür, Türkiye ile Hazar Denizi'ni birleştirmektedir. Samtskhe-Cavakheti, Akhaltsikhe, Adigeni, Aspinza, Akhalkalaki, Borcomi ve Ninosminda belediyelerinden oluşmaktadır. Bölgede 270 iskân yeri vardır. Bunlardan beşi şehir: Akhalkalaki, Akhaltsikhe, Borcomi, Vale, Ninosminda; yedisi kasaba: Bakuriani, Bakurianis Andazeti, Tsağveri, Akhaldaba, Adigeni, Abastumani, Aspinza olup bölgedeki köy sayısı 258'dir (Balasaniani, 2016: 42). Akhaltsikh şehri 312 y1l (1266-1578) SamtskheSaatabago'nun, 300 yıl (1579-1829) Çıldır, nâm-1 diğer Ahıska Eyâleti'nin, daha sonralar Rus yönetiminde Akhaltsikh Kazası'nın, Sovyet yönetiminde ise Akhaltsikh Rayonu'nun ve bağımsızlık kazandıktan sonra da hem Akhaltsikh Belediyesi'nin hem de SamtskheCavakheti'nin merkezi olmuştur. Akhaltsikh çok önemli stratejik bir konumda olup Anadolu’yu Kafkaslara birleştiren Büyük İpek Yolu güzergahında idi. Büyük İpek 
Yolu'nun bu güzergâhı, Rustavi-Orpola-Kopadze-Minedze-Çeçerek-Akhaltsikh olmuştur. Bizans istikametine ise kervanların geçtiği güzergâhı şöyle özetliye biliriz:

1. Tsunda-Tmogvi (Tümek), Niala, Havat, Gumbati, Samtsubi, Akhalkatsi, Çorço, Tbeti, Şabanibeli;

2. Tsunda-Tmogvi (Tümek), Zeda Tmogvi (Yukarı Tümek), Grdzeli Çala (Uzun Çala), Shalnara, Çura, Mepis Skaro (Kral Pınarı), Dadeş Yolları, Çobaret, Puğa, Tskorza, Ortakaravi, Şabanibeli;

3. Hospia, Oldan, Göle, Ardahan, Şavşat, Klarcet-Kara Deniz Kıyısıyla (Datukişvili, 2009: 41-42).

Çalışmamızın ana kaynağını Tapu ve Kadastro Genel Müdürlüğü Tapu Arşivi Dairesi Başkanlığı Tapu Tahrir Defterleri içinde yer alan 130 nolu 1003 Hicri (1595 Miladi) tarihli tahrir defteri ve bu defterin Tbilisi'de 1947 yılında Cikia tarafından Osmanlıca baskısı olan“Defter-i Mufassal Vilâyet-i Gürcistân” kitabı oluşturmaktadır. Bu kaynak, XVI. yüzyıl sonlarında Sakuneti Köyü'nün sosyal ve ekonomik yapısınının sergilenmesi bakımından çok önem teşkil etmektedir

1595 tarihli tahrir defteri kayıtlarına göre Sakuneti Köyü'nde 17 hane bulunmaktadır. Bunlardan 14 hane vergilendirilmiştir. Mehmet Abdullah oğlu ise kiraladığı Giorgi Keşiş ve kardeşi Mehrebil'e ait bir hisse bağ için yılda maktu olarak 20 akçe ödemektedir. Vergi vermeyen ise Giorgi keşiş ve kardeşi Mehrebil idi.

Sürgün sonrası Sakuneti köyünü ziyaret eden Cemşit Halit hatıralarında köyün her tarafının bahçeler ve ekili tarlalarla süslenmiş olduğunu yazmaktadır (URL-1). Köyle ilgili Osmanlı kaynaklarında rastladığımız ilk bilgi 1595 tarihli tahrir defterindedir. Sakuneti Köyü o dönemde Çıldır Eyâleti Ahıska Sancağı Azğur Nahiyesi'ne bağlı bulunmaktaydı.

\section{Sakuneti Köyü'nün Tarihçesi}

Sakuneti Gürcüce зððбつmº (kuneli) kelimesinden oluşmuş ve Rusça “боярышник” (Latince: Crategus) anlamını ifade etmektedir (Kankava, 2001: 164). Bunun da anlamı ise "akdiken"dir. Zisserman ve Veydenbaum'da da "Sakuneti"- место боярышника akdikenlik yer anlamındadır (Zisserman, 1870: 3; Veydenbaum, 1878: 178). Sakuneti Köyü’nün eski adı "Sağvineti” olarak da bilinmektedir (Nikolaişvili, Sartania ve Ucmacuridze, 2016: 55). Bu isimden köyün bağcılıkla yakından ilgisi olduğu görülmektedir.

Milad öncesi 713 yılında Gürcistan sınırları içerisinde Sakinet adlı şehrin inşa edildiği bilinmektedir (Ahıska və Ahıskalılar, Bizim Asır. Müsteqil ictimai-siyasi qezeti, say1 28). Sarkine olarak da bilinen bu güçlü kalenin (Kartlis Tskhovreba, 2008: 19-20; Mroveli, 1979: 28; URL-25) Sakuneti köyü ile lgili olduğu fikrini doğru bulmuyoruz. Zira Allen'e göre Sarkine / Sarkinet şehri başkent Mtskheta'nın doğu-kuzeyinde ve Kakhet'te Küçük Alazan çayı üzerinde yerleşmiş bulunmaktadır (Kırzıoğlu, 1992: 19). Başka bir kaynak da Sarkineti'nin Mtskheta'nın batı tarafında olduğunu bildirmektedir (Ketskhoveli, 1971; 7; Apakidze, 1963: 206). Günümüzde Sarkineti isminini taşıyan köy, Gürcistan Cumhuriyeti'nin Dmanisi Belediyesi'ne bağlı olup belediye merkezinden 28 km uzaklıkta yerleşmektedir (URL-26). Sarkineti, Sarkineti, Ganakhleba ve Velispiri'den oluşan nahiyenin merkezidir. Köyde 2014 nüfus sayımına göre 48'i bay, 48'i bayan olmakla toplam 96 kişi oturmaktadır (URL-27).

9 Ağustos 1578 tarihinde Zurzna ve Tsintsal köyleri arasında yerleşen Çıldır Düzü’nde (Lomsadze, 1999: 20; Kırzıoğlu, 1998: 289) Osmanlı-Safevi Savaşı Osmanlıların zaferi ile 
sonuçlandı. 10 Ağustos tarihinde Ahıska, Ahılkelek, Tümek ve Hertvis kaleleri Osmanlılarca teslim alındı (Gümüş, 2000: 165) ve 1 Temmuz 1579 yılında Çıldır Beylerbeyliği (Eyâleti) kuruldu (Gümüş, 2000: 192; Kılıç, 2008: 114: İnbaşı, 206: 78).Sakuneti köyü de o tarihten itibaren Osmanlı sınırları içerisine katılarak Ahıska Sancağı Azğur Nahiyesi'nin köyü haline geldi. XV-XVI yüzyıllardan kalma Kutsal Giorgi kilisesi, yaklaşık 1927'de yapılmış camii ve okul vardır. Sakuneti Köyü'nde ortaokul ve kütüphane faaliyet göstermektedir. Günümüzde Sakuneti'de 2 yerleşkeli okul bulunmaktadır. Okulun toplam alanı 562 km.karedir. 16 öğretmeni ve 96 öğrencisi olan bu okulda 5 bilgisayar öğrencilerin hizmetine sunulmuştur (URL-4). 1870 tarihinde köyde okulun bulunduğu kayıtlardan belli olmaktadır (Zisserman, 1870: 3).

\section{Sakuneti Köyü'nde Tarihi Anıtlar}

Sakuneti köyünde iki önemli tarihi anıt; cami ve kilise bulunmakta olup onların arasındaki mesafe 40-50 m.dir (Resim 1).

Resim 1. Kilise ve Cami Sakuneti Köyü’nün Ortasında

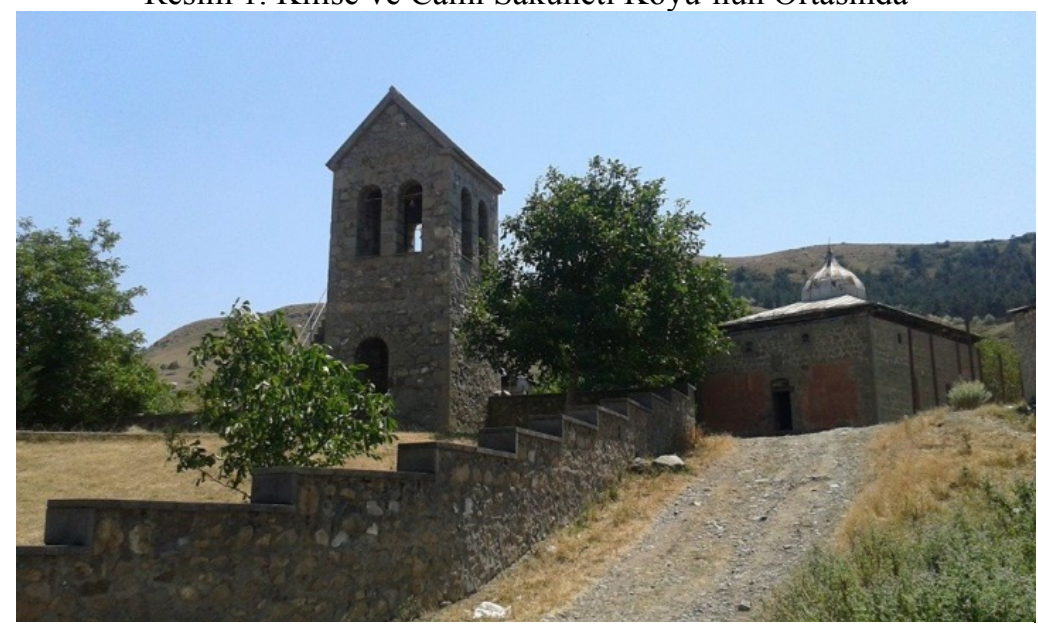

Sovyetler zamanında cami kültür evi, sinema kulübü, depo olarak kullanılmıştır.

\section{Sakuneti Kutsal Giorgi Kilisesi}

Sakuneti köyündeki Kutsal Giorgi kilisesinin küçük kubbesi olup girişi güney taraftadır. Kilisenin bazı kaynaklarda XII. yüzyıl, bazı kaynaklarda da XV-XVI. yüzyıllara ait olduğu bilinmektedir. Kilise çok iyi korunmuş şekildedir. Onun yalnız duvarları değil çatısı da sağlam bir haldedir. Sakuneti Kilisesinin böyle iyi korunmasının en büyük nedeni yerli Müslüman halkın bu kiliseye kendi tarihi anıtı gibi değer vermesinden ileri gelmektedir. Zira Sakuneti köyü sakinleri islam dinine girdikleri ilk zamanlarda kilisede eski geleneklerini sürdürmekte idiler. Geceler kilisede mumların yakıldığı ve kilisenin sabaha kadar aydınlatıldığı bilinmektedir (Caparidze, 2008: 37). Samtskhe-Cavakheti'de böyle iyi korunmuş kilise sayısı çok azdır. Galustagil sülalesinden olan Bakhşi hatıralarında yazıyordu ki, kilisenin iki çanı vardı ve bunları dedesi Ömer Potskhveradze'nin dedesi tarafından indirilip evinde saklanılmıştır. Bu çanlardan biri büyük, diğeri küçük idi. Küçük çanı 1938 yılında açılan okula verilerek okul zili olarak kullanılmıştır (URL-7. Galustov'nun 23.03.89 tarihli mektubu). Her yıl 23 Nisan'da Giorgioba bayramı gününde komşu ortadoks köylerden gelip burada kendi törenlerini düzenlemekteydiler. Yerli 
Müslüman halk ise onların törenlerine saygı duymaktaydılar. Sakuneti Kutsal Giorgi Kilisesi resim 2'de gösterilmiştir (URL-9).

\section{Resim 2: Kutsal Giorgi Kilisesi}

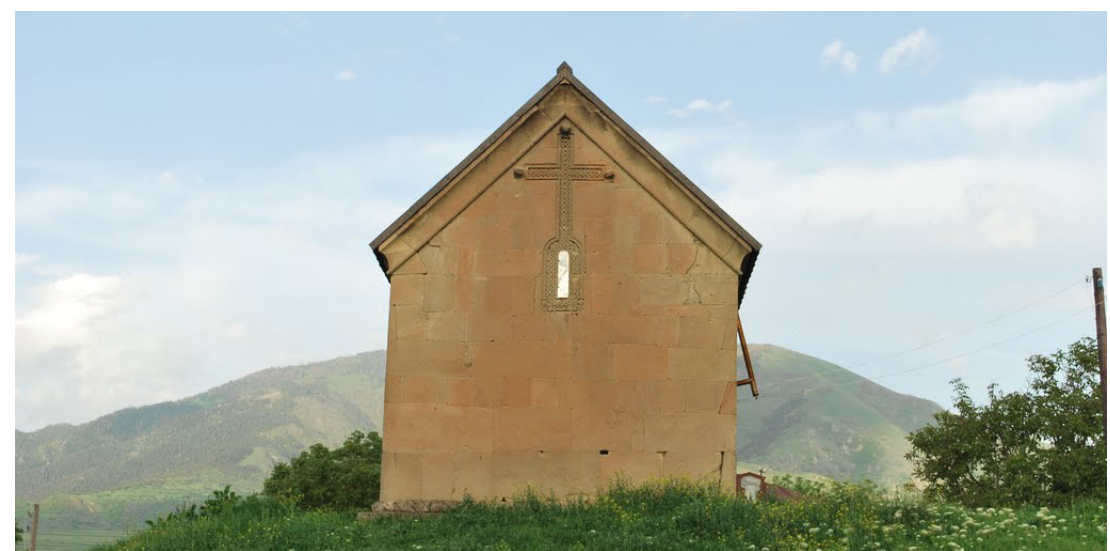

Kaynak: URL-9

Sakuneti Köyü ihtiyarlarının verdiği bilgilerden hareket ederek şunu söyleye biliriz ki, yaşlılar kilisenin güney tarafında oturup konuşurlarmış. 1913 yılında bir yabancı seyyah Sakuneti köyünü ziyaret edip kilisenin de resmini çekip yayınlamış. Kilsenin yanında Petrekgil'den Müslümanın da bulunduğu görülmektedir (Resim 3).

Resim 3: Sakunet Köyü’ndeki Kilise ve Onun Yanında Petrekgil Sülalesinden Bir Şahıs. Y1l 1913.

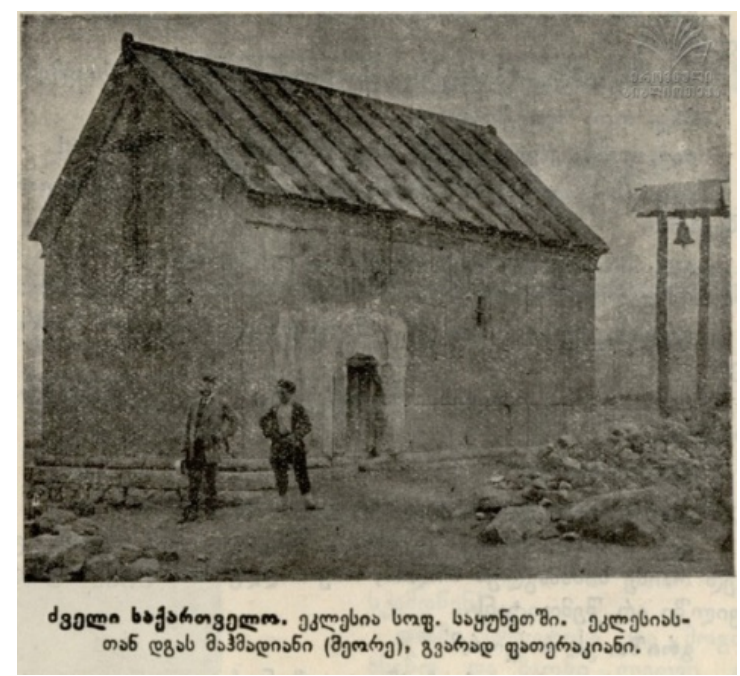

Kaynak: URL-10

Natia Gogolaşvili yazısında civarda dolaşan şöyle bir tarihi olayı dile getirmektedir: "Azğur Köyü’nden biri Giorgoba bayramı gününde kilise yanında bir koyunu kurban kesiyor. O, gece rüyasında bir ses duyuyor: "Ben ne yaptım? Benim günahım ne?”. Ertesi gün aynı kişi köye geliyor ve bir koyunu da cami etrafında dolandırdıktan sonra kurban 
kesiyor". Sakuneti'de böyle tarihi olayların çok olduğunu Gogolaşvili yazmaktadır. Kilise günümüzde faaliyette olup cami ise çalışmamaktadır. Cami üzerindeki yazıya göre onun inşa tarihi 1927'dir (URL-13). Gürcistan Kültür Bakanlığı N3/86 NO ve 24 Mart 2012 tarihli kararıyla Samtskhe-Cavakheti'deki camilere Kültürel Miras Anıtları Statüsü verildi ve Osmanlı tipli klâsik üsluplu (Bekadze ve Yiğit, 2016: 253) camilerden olan Sakuneti Köyü camisi (Resim 4) de bu statüsü alanlardandır (URL-12).

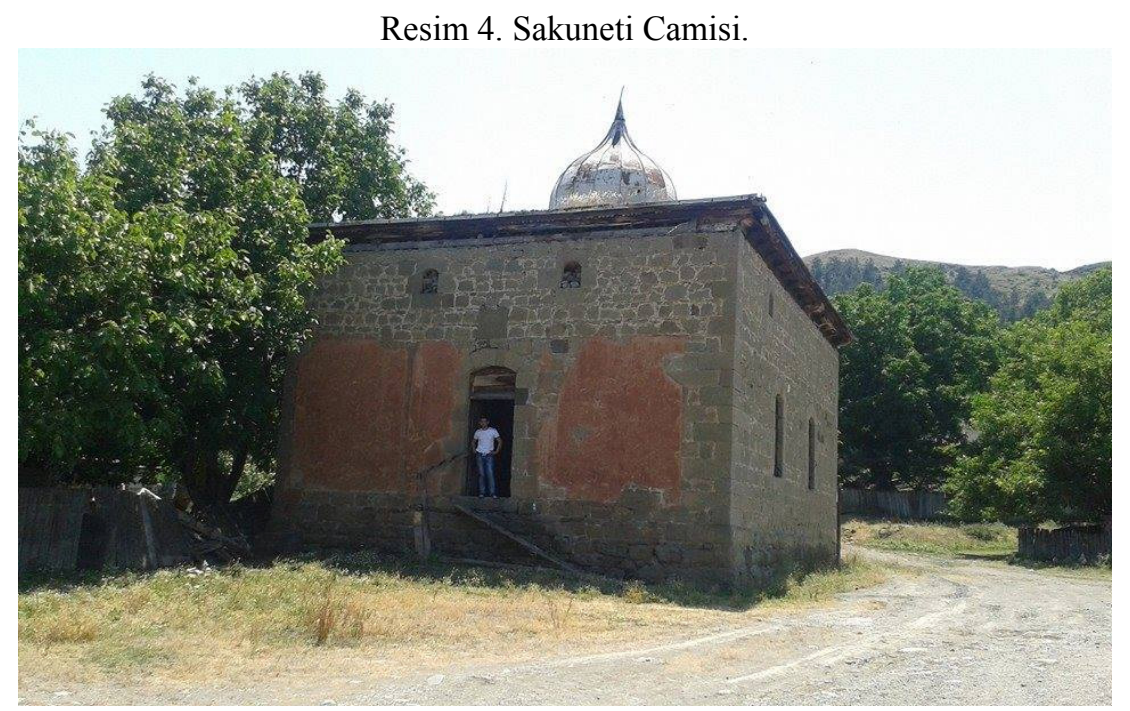

Kaynak: URL-11 (Resim Cemşit Halit Kapitsgil'e Aittir)

Cami, Sakunetli köy sakinlerinden, Yordanidze ve Potsxveraşvililer tarafindan yaptırılmıştır (URL-8). Başka bir kaynak ise caminin Mekke'ye gidip hac görevini yapan Khurtsidze $^{1}$ ve Yordanidze'ler tarafından inşa edildiği bilinmektedir (URL-14). Sakuneti Camisi zırhlı başlıklı küçük miğferli klâsik üsluplu inşa ediilmiş camilerdendir.

14 Kasım 1944 sürgününden sonra Sakuneti köyüne yerleştırilen Hıristiyan halk bir ibadet yeri olarak camiye de saygı göstermekteydiler. Bu yüzden Sovetler zamanında caminin depo olarak kullanılmasına itiraz etmişlerdir. Fakat onları yerli yönetim dinlememiş ve camiyi amacı dışında kullanmışlardı. Hatta değilene göre bu emri verenin sülalesi zaman zaman hastalıklar geçirmiş ve o sülaleden kimse kalmamıştır (Kişisel Görüşme: Bekadze. 18.03.2017). Ayrıca Sakuneti’ye getirilen halk hem Müslimlerin hem de gayrimüslümlerin inancının tek bir varlıktan ibaret olduğunu çok iyi biliyorlardı.

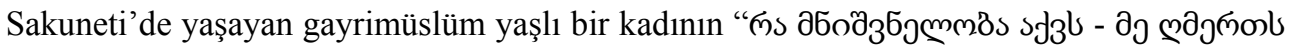
З "ne önemi var ben "Ğmerti" diyorum, o Allah diyor" (URL-23).

Kapitsgil'den olan Cemşit Halit hatıralarında şunları yazmaktadır: "Caminin yanında yaşlı bir teyzenin evi var, teyze bize su verdi, ben mezarlığın nerde olduğunu sordum. O bana dağın dibinde olduğunu söyledi. Malesef yol bozuk olduğu için ve acele ettiğimiz için gidemedik. Önce camiyi gezdik. Cami sapasağlam ayakta, ama içi biraz restorasyon ister, ön duvar çatlamış. Gürcistan devleti 2016 - 17 yıllarında Sakunet ve

\footnotetext{
${ }^{1}$ Cami Khurtsidze değil Potskhveradze ve Yordanidze tarafından yaptırılmıştır.
} 
Harcam camilerin restorasyonunu yapacakmış. Caminin içinde çok güzel duvar ve ağaç süslemeleri var. Sonra kilisenin yanına gittim. Kilise 12 yüzyılda yapılmış sonra 15 yüzyılda restore edilmiş. İçine giremedik çünkü kapısı kapalıydı. Sürgünden önce buraya başka bölgelerden gelen hristyan Gürcüler kendi bayramlarını kutluyordular ve müslümanlarda bunlarla beraber kutlamalara katılıyordular" (URL-1). Kür Nehri ve köydeki cami ve kilise köye ayrı anlam kattığından burası köy timsalında küçük bir Kudus'u hatırlatmaktadır.

Şu hususu da bildirmek istiyorum ki, Sakuneti camisinin yapım tarihi 1927 yıl olduğucami üzerindeki kayıttan belli görülmektedir. Fakat 1870 tarihli belgede köyde mescidin olduğu bilinmektedir (Zisserman, 1870: 3). 1870 tarihli kayıtlı mescitin tahta bir yapı olduğu şüphesizdir. Daha sonralar onun yerine taştan yapılmış cami inşa edildiği kesinlik kazanmaktadır.

\section{Köyün Coğrafi Konumu}

41 ${ }^{\circ} 41^{\prime} 12^{\prime \prime}$ Kuzey $43^{\circ} 07^{\prime} 46^{\prime \prime}$ Doğu meridiyenleri arasında yer alan Sakuneti, SamtskheCavakheti Bölgesi Akhaltsikh Belediyesi'nin en güzel köylerinden biridir. Resim 5.

Resim 5. Sakuneti Köyü’nün Görüntüsü

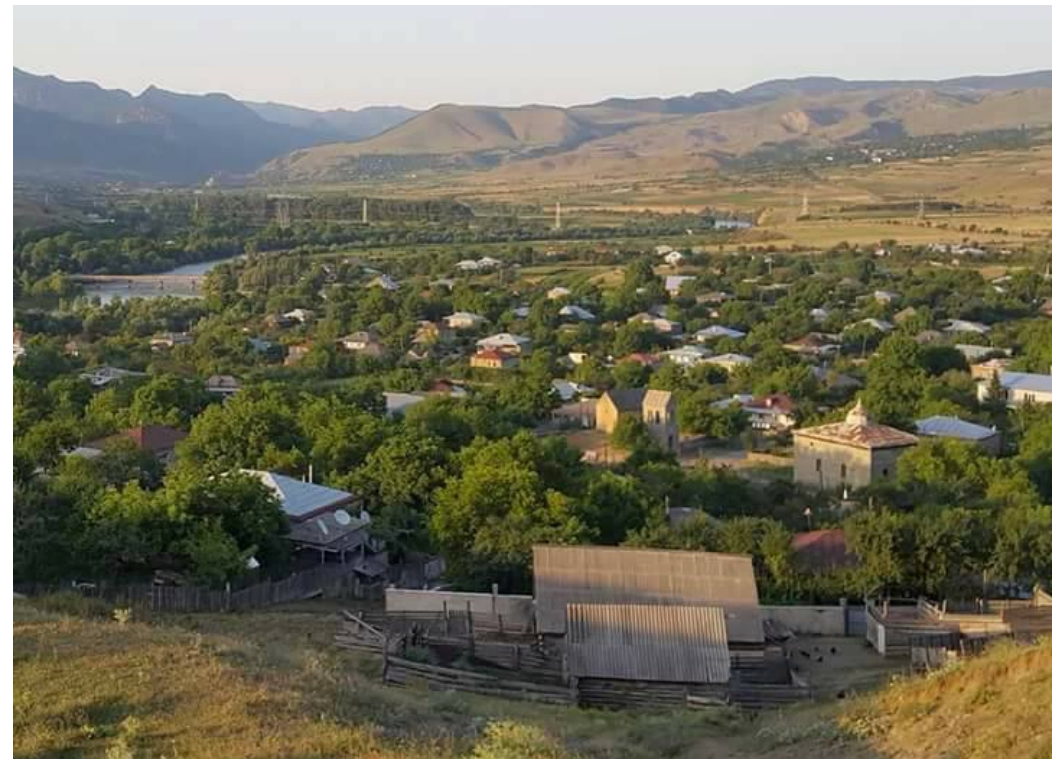

Kaynak: URL-2

Sakunet Köyü, Gürcistan Cumhuriyeti Samtskhe-Cavakheti Vilâyeti'nin Akhaltsikh Belediyesi Agara nahiyesinin terkibinde olup Kür Nehri'nin sağ tarafindaki Tupi Tepesi'nin eteğinde yerleşmektedir. Rakımı $900 \mathrm{~m}$. olup Akhaltsikh'den $22 \mathrm{~km}$ uzaklıktadır. Komşuları, batısında Kür Nehri'nin sol kıyısında Agara, Kuzeyinde Tkemlana, güneyinde Kopadze Köyü, doğusunda Tisel köyü bulunmaktadr. Sakuneti köyünü, nahiye merkezi Agara ile Kür nehri üzerindeki körpü birleştirmektedir (Resim 6). 
Resim 6: Agara ile Sakuneti Köylerini Birleştiren Köprü

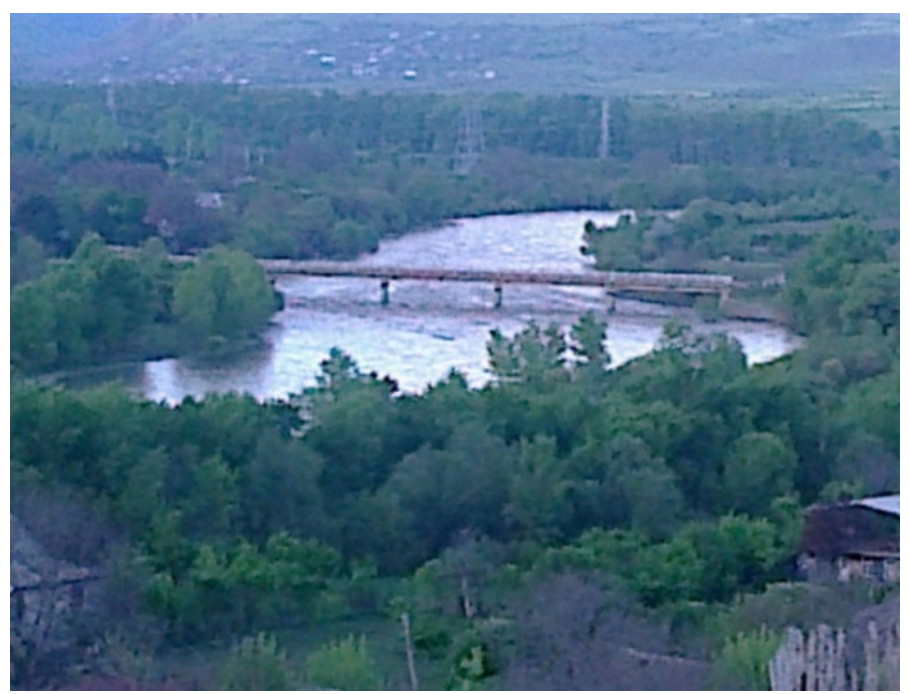

Daha önceler bu iki köyün arasındaki geçit navla² sağlanmaktaydı. Sakuneti ile Kvaltakhevi (Koltakhev) köyleri arasında da "Şakir dedenin hayır köprüsü" adlanan bir köprü de bulunmaktaydı (Kişisel Görüşme: Hayrettin Keskin, 1944 Sakuneti Doğumlu).

\section{Sakuneti Köyünün İklimi}

Samtskhe-Cavakheti iklimi birbiri ile farklılık göstermektedir. Samtskhe kuru, subtropik dağ havası ikliminde olup kışı kısa karlı ve ılımlıdır. Yazı uzun sürelidir. Fakat Cavakheti bölgesi kuru hava ve kışı soğuk ve uzun sürelidir. Yazı serindir (Gaprindaşvili, 2016: 16). Sakuneti Köyü, Samtskhe Bölgesi'nde olduğundan onun iklimi de soğuk ve 1lımlıdır. En kurak aylarda bile yağış oldukça fazladır. Yaz mevsiminde sıcaklık fazladır. Yıllık ortalama sıcaklık 8,2'dir. Yağmur ilkbaharda daha fazladır. Ortalama yağış miktarı 687 mm'dir. Sakuneti Köyü'nde olan şiddetli soğuk insana pek fazla etki göstermezdi.

\section{Flora ve Fauna}

Akhaltsikh Bölgesi, zengin bitki örtüsü ve orman alanları ile kaplıdır. Yaylalardakı çiçekler çevreye hoş bir koku veriyor. Arılar bu çiçeklerden bal yaparlar. Bölge faunasının da zengin olduğu bilinmektedir. Bölgede geyik, ceylan, dağ keçisi, yabanı domuz, su samuru, vaşak, yabanı kedi, ayı, yılan, tilki, porsuk, gelincik, tavşan, sincap, su faresi, orman faresi, kuşlardan, güvercin, yabanı güvercin, kumru, karga, saksağan, sığırcık kuşu, bıldırcın, yaban tavuğu, kara kurbağası, kertenkele, çimen yılanı, yeşil kurbağa, göl kurbağası, nehirde alabalık vs bulunmaktadır. Ahıskalılar Saksağan'a kaçkaçi derlerdi. Ve sabah sabah birinin evine kaçkaçi gelip ötseydi o eve iyi bir haber veya misafir geleceğini bildirdiği düşünülmekteydi (Valida Ak, Kişisel Görüşme, 05.03.2017). Sakuneti Köyü bu zenginliklerden faydasını almaktadır.

\section{Sakuneti Köyü'ndeki Akarsular, Dă̆, Tepe ve Tarlalar}

Kafkasya'nın en büyük ve en önemli nehri Kür, Sakuneti köyüne süs ve canlılık vermektedir. Sakuneti köyü nehrin sağ kıyısında yerleşmektedir. İslam kaynaklarında elMelik, el-Kurr, Grek ve Lâtin kaynaklarında Lyros, Cyrus, Batı dillerinde Kur/Kura

\footnotetext{
${ }^{2}$ Nav- Sal demektir.
} 


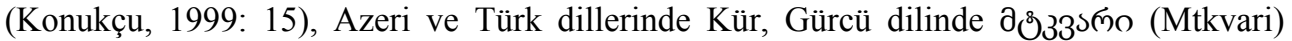
olarak söylenen bu hidronim Türkçe ve Moğolca'da yiğit, kabadayı anlamına gelir (Gülensoy, 1984: 93). Başlangıcını Türkiye'de Kuzey-Doğu Anadolu'nun Allahüekber ve Yalnızçam dağlarından $2742 \mathrm{~m}$ yükseklikten almaktadır. Uzunluğu 1515 km'dir. Havzasının genişliği $188000 \mathrm{~km}^{2}$. Vardzia (URL-5) taraftan Gürcistan topraklarına girip Hertvis, Aspinza, Minedze, Sinis, Sakuneti, Agara, Taşiskari köylerinden ve Borjomi, Gori, Mtskheta, Tiflis, Rustavi, Azerbaycan'ın Mingeçevir, Yevlakh, Sabirabad (burada Aras Nehri ile birleşmektedir), Şirvan, Salyan şehirlerinden geçerek Neftçala ilçesinde Hazar Denizi'ne dökülüyor. Kür Nehri'nin Akhaltsikh Belediyesi sınırları içerisindeki uzunluğu 40 km.dir. Nehrin suyu yazın artmakta güzün azalmaktadır. En az su miktarı kış aylarındadır (URL-6). Sakuneti'te bu nehrin üzerinde 2012 de tamamlanması planlaştırılan büyük Su Elektrik Santralı inşa edilmektedir. Bunun için gerekli baraj Aspinza ilçesinde olup 7,6 kmlik tunellee Sakunete birleştirilmiştir. Yeni teknolojiye uygun olarak 1000 megavat gücünde elektrik santralı 43 hektar alanda kurulmaktadır. Bu yalnız Gürcistan'da değil tüm Kafkasya'da fevkalede bir proje olarak değerlendirilmiş ve elde edilen enerji hem komşu Türkiye'ye hem de Avrupa ülkelerine elektrik enerjisinin sağlanması öngörülmüştü. İnşaatı 2010'da başlanması ve 2013'de tamamlanması karalaştırılmıştı (URL-3). Gürcistan Maliye Bakanlığg'nın 2016 yılı 6 aylık bütcetin yerine getirilmesi konusundakı bilgilerinden de anlaşıldığına göre Sakuneti Su-elektrik Santralı'nın gücü 10.4 megavat olduğu bildirilmiştir (Sakartvelos Pinansta Saministro, 2016: 104).

Sakuneti'den bakıldığında Kür Nehri'nde iki ada bulunmaktaydı. Bunların biri "Yukarki Ada", diğer "Aşağki Ada"olarak adlandırılmaktaydı (Kişisel Görüşme: Hayrettin Keskin, 1944 Sakuneti Doğumlu).

Elasura Deresi Sakuneti köyü topraklarının sulanmasında çok önem arz etmekteydi. Elasura Deresi, Orpola, Blorza ve Kopadze taraftan gelip Sakuneti tarlalarından geçerek Kür Nehri'ne dökülmekteydi. Elasura Deresi yağmurdan kaynaklandığından bazen de suyu olmazmış. Bu yüzden Kopadze taraftaki şlyuzlar ${ }^{3}$ kapatılıp su birikimi sağlanıyordu. Ayrıca Sakuneti ile Kvaltakhevi (Koltakhev) köylerini ayıran Sakrolan ve Solatkhevi dereleri de ekinlerin sulanmasında önem arz etmekteydi (Kişisel Görüşme: Hayrettin Keskin, 1944 Sakuneti Doğumlu).

Köyün değişik yerlerinde yer alan Satave, Motkhe, Agara Köyü taraflarındaki Çalikana, Sehravi, Cincola, Kldezeri tarlaları ve Kür Nehri’nin kenarındaki Çala tarlası köyün verimli toprakları içerisinde yer almaktadır (Kişisel Görüşme: Hayrettin Keskin, 1944 Sakuneti Doğumlu).

Sakuneti köyü karşısında Tupi Tepesi yerleşmiş bulunmaktadır. Sakuneti eski öğretmenlerden Galustagil'den olan Bakhşi Galustov ise bu tepenin Ruget Dağ1 bildirmektedir (URL-7. Galustov'nun 23.03.89 tarihli mektubu). Çakhalov Nüsrettin köyün sağ tarafındaki tepenin de Kldezeri Tepesi olduğunu yazmış bulunmaktadır.

\section{Sakuneti Köyü'nde Doğal Afetler}

\section{Sakuneti Köyü'nde Toprak Kayması (Heyelan)}

Heyelanlar, doğal afetlerden olup kütle hareketleri, jeolojik-jeomorfolojikklimatolojik-meteorolojik etken sayesinde yamaç dengesinin (stabilitesinin) bozulmasıyla ortaya çıkmaktadır”. Heyelenlar aynı zamanda yer kayması olarak da bilinmektedir. Yer kayması, toprağın hareketi sonucunda şekil ve yer değiştirmesidir. Bu, genelde yağmurlar

\footnotetext{
${ }^{3}$ Şlyuz- alavera havuzu.
} 
sayesinde oluşmaktadır. Yer kayması Samtskhe-Cavakheti Bölgesi'nin Akhaltsikh Belediyesi'nin Azğur, Tisel, Tkemlana, Gurkel, Ani, Abi, Naokhreb, Adigeni Belediyesi'nin Ude, Varkhan, Abastuman, Ttsakhnitskaro, Aspinza Belediyesi'nin Aspinza Kasabası, Nekelekevi, Atskvita, Kuntsa ve Rustavi'de olduğu gibi Sakuneti köyünde de tesadüf edilmektedir (Gaprindaşvili, 2016: 88-105). Köyün üst kısmında Tupi Tepesi yakınlarında "1956 yılındaki kayma bunun bir örneği olarak görülmektedir" (Gaprindaşvili, 2016: 93; Samkharadze, 2013: 54). (Resim 7).

Resim 7: Sakuneti Köyü’nde Toprak Kayması

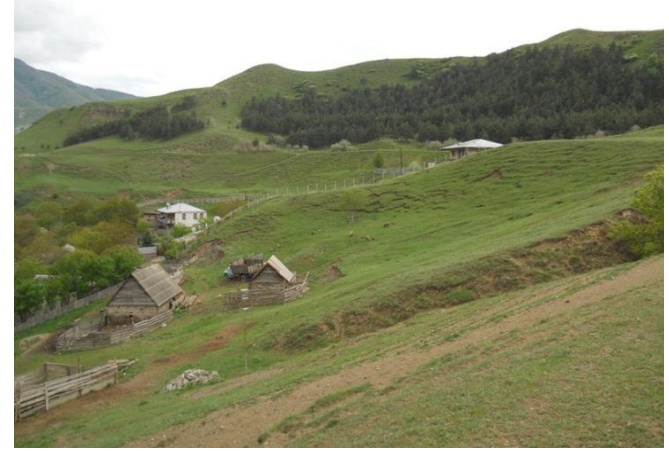

Kaynak: Gaprindaşvili, 2016: 93.

Kür nehri kıyılarında toprak kayma olaylarına sık sık rastlanılmaktadır (Resim 8).

Resim 8: Kür Nehri’nde Toprak Kayması ve Aşınmalar

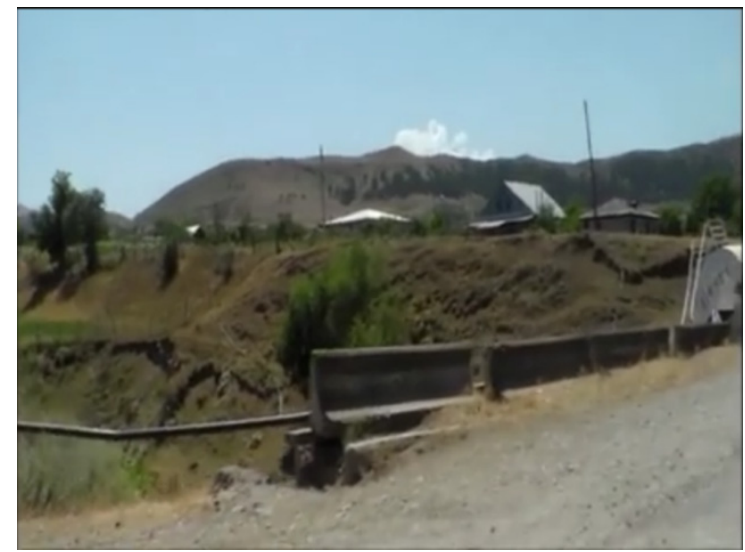

Kaynak: Cemşit Halit’in Hazırlamış Olduğu Video Gösterisi

\section{Sakuneti Köyü'nde Toprak Aşınması (Erozyon)}

Erozyon (toprak aşınımı), toprağın su ve rüzgârın etkisiyle aşınması ve taşınmasıdır. Onun başlıca nedeni toprağın üzerindeki bitki örtüsünün bulumamasıdır. Akhaltsikh şehrinde Posof çayının sol, Akhaltsik-Muskhi-Uraveli yolu üzerinde Uraveli çayının sol, 
Naokhrebi köyünde Posof çayının sağ, Varkhan köyünde Otskhe deresinin sağ, Otaskhevi çayında, Nekelekevi, Atskvita, Kuntsa ve Rustavi köylerinde Kür nehrinin sol sahilinde toprak aşınma olaylarına rastlanmaktadır (Gaprindaşvili, 2016: 91-1059. SakunetiTkemlana (Temlala) arasında, nehrin gerek sağ gerekse de sol tarafta büyük aşınmalar bulunmaktadır (Gaprindaşvili, 2016: 91; Gaprindashvili, Gerkeuli, Tsereteli ve Gaprindashvili Merab, 2016: 320) (Resim 9 ve 10).

Resim 9: Tkemlana ve Sakuneti Arasında Kür Nehri’nin Să̆ Sahilinin Yıkanıp Aşınması

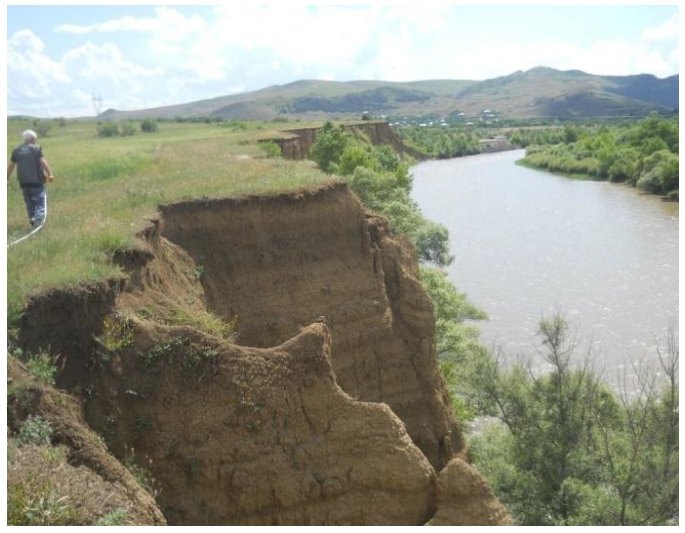

Kaynak: Gaprindashvili, 2016: 91

Resim 10: Tkemlana ve Sakuneti Arasında Kür Nehri’nin Sağ Sahilinin Yıkanıp Aşınması

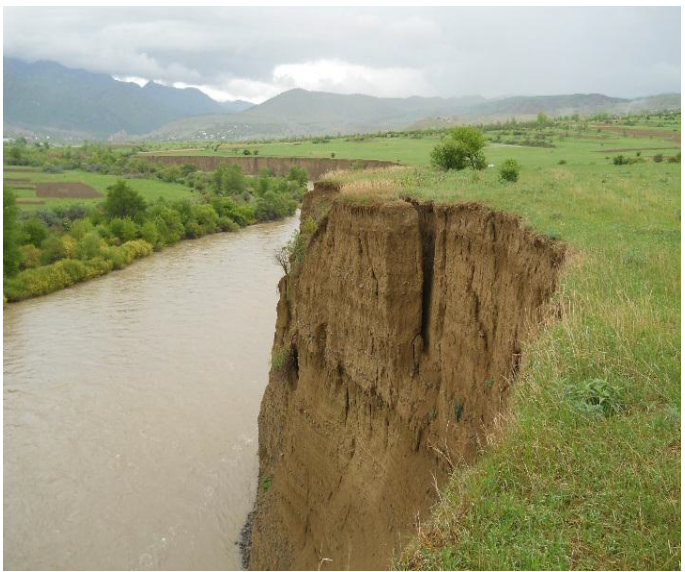

Kaynak: Gaprindashvili, 2016: 91

\section{Depremler}

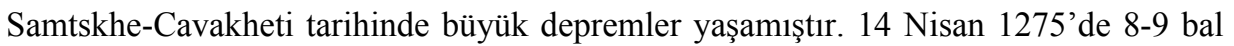
gücünde Azğur, 31 Aralık 1899'da 9 bal gücünde Akhalkalaki, 12 Ekim 1912'de 6 bal gücünde Aspinza, 7 Mayıs 1940'da 8 bal gücünde Tabatskuri depremlerinin örnek 
verebiliriz (Gaprindaşvili, 2016: 51). Azğur depreminden Sakuneti köyünün de etkilendiği muhtemeldir.

\section{Sakuneti Köyü'nün Sosyal Durumu}

Çıldır Eyâleti'nde tarım ve hayvancılıkla uğraşan halkın büyük çoğunluğu çiftçi ailelerden oluşmaktadır. Köy, kasaba ve nahiye gibi kırsal yerleşimler bir idarî birimlerdi. Köylerde Müslüm ve Gayrimüslümler bazen komşu olarak bazen de değişik mahallelerde yaşamaktaydı. Bu iki topluluk Osmanlı Devleti'nde din farkı gözetmeksizin "reaya" adlandırılmaktaydı. Sakuneti köyü bu dönemde çoğunlukla Gayrimüslümlerden oluşmaktaydi.

\section{Nüfusu}

XVI. yüzyılda Çıldır, nâm-ı diğer Ahıska Eyâleti'nde sosyal-ekonomik hayatın ağırlık merkezini köyler teşkil etmekteydi. Yerleşik hayata geçmesinden ve halkın geçiminin genellikle tarım vasıtasıyla temin etmesinden dolayı köy ekonomik hayatı genel ekonominin tek vericisi idi (Akdağ, 1995: 25). Tahrir defterlerindeki kayitlar sayesinde her hangi bir yerleşim yerinin nüfus yapısını öğrenmek mümkündür. Bu defterlerdeki nüfus, vergiye esas olan nüfus olduğundan her hangi bir yerleşim yerindeki her hanenin kaç kişiden oluştuğu belli değildir. Bu yüzden, 1595 tarihli tahrir defterindeki isimler, o tarihteki gerçek nüfusu tam yansıtmamaktadır.

1595 tarihli tahrir defterine göre Ahıska Sancağı Azğur nahiyesine bağlı olan Sakuneti köyü 17 haneden oluşmaktadır. Osmanlı zamanında hane vergi için düzenlendiğinden her hanenin kaç kişilik aile olduğu tartışma konusu olmuş ve nüfus hesaplamalarında genel olarak Ömer Lütfü Barkan'ın kabul ettiği "5 kat sayısı" ile çarparak toplam nüfus bulunmaktalar (Göyünç, 1997: 552; Dalgalı, 2008: 27). Bazı araştırmacılar bu sayıyı az bulup onu "6" (Gül, 2009: 1036) ve “7” (Göyünç, 1979: 332), Andre Raymond ise XVIXVII. yüzyıl Halep nüfusu ile ilgili yazısında "8” (Gül, 2009: 1036) olarak kabul etmektedirler. Bulgar tarihçi Maria N. Todorova Balkan Bölgesi için katsayısını 7 olarak belirtmiştir (Çaçan, 2015: 15). Halil İnalcık hatta bu katsayıyı XV. yüzyıl Bursa'sı için 9 olarak ortaya koymaktadır (Göyünç, 1997: 552-553). Genç araştırmacı Shota Bekadze Çıldır, nâm-1 diğer Ahıska Eyâleti nahiyeleri ile ilgili çalışmalarında; XVII. Türk Tarih Kongresi'nde sunduğu "Osmanlı Arşivleri-Bir Kültür İmparatorluğu” bildirisinde, "XVI. Yüzyılda Çıldır Eyaleti Ahıska Sancağı'nın Politik ve Sosyo-Ekonomik Durumu” konulu Yüksek Lisans Tezi'nde ve makalelerinde hanede "8" katsayısını uygun bulmaktadır (Shota Bekadze, 2012: 8; Shota Bekadze, 2014a: 10; Shota Bekadze, 2014: 66). Biz de Shota Bekadze'nin hanede 8 katsayısının Sakuneti köyü için de nüfus hesaplamaları için uygun görmekteyiz. Zira Ahıska Eyâleti sakinlerinin aile büyüklüğü 5-8 çocuk arasındadır. Bu durumda nüfus $=$ hane x 8 şeklinde olur. Her hanede 8 kişinin yaşadığını kabul edersek Sakuneti köyünde 136 kişinin ikamet ettiğini görebiliriz. Köyün Azğur nahiyesinde nüfusu en fazla olan köylerden ilk beşe girdiğini kayıtlardan görmek mümkündür. Köydeki hane reislerinden 16'sı gayrimüslim ve biri ise Müslümandır. 1595 yılında nüfusu 136 kişi olan Sakuneti köyündeki, nüfus daha sonralar şöyle değişmektedir: 1870'te 47 ailede 320 kişi olmakla 172'si bay, 148'i bayan (Zisserman, 1870: 3), 1886'da 67 ailede 499 kişi (286 bay, 213 bayan) (SSDZK, 1893: 66-68), 1917'de 115 ailede 759 kişi (393 bay, 366 bayan) (Selskokhozyaystvenniy perepis, 1917), 2002'de nüfusu 593 olan (301 bay, 292 bayan) (2002 Nüfus Sayımı, s. 180), 2014'te ise nüfus 472 kişi (242 bay, 230 bayan) (URL-272014 Nüfus Sayımı) olarak bulunmaktadır. 1944'te Sakuneti köyünde 204 hane 855 kişi bulunmaktadır (Chakhalov Nüsrettin). Bu iyi gelişmiş köy Azğur'un yakınlığında olup onun 5-6 km uzaklığındadır (Proneli, 1991: 45-46). Aleksandr Proneli'nin bildirdiğine göre 
Sakuneti XX. yüzyıl başlarında büyük köy olup köy halkı büyüklü-küçüklü hepsi Gürcü dilini biliyorlardı. Soyadları ise aynı Kartli ve İmereti'de olduğu gibi korunmuştu (Beridze, 2006: 19).

Sakuneti köyü Müslüman halkı 14 Kasım 1944 yılında Özbekistan ve Kazakistan’a sürgün edildi. Özbekistan'a sürgün edilenler çoğunlukla Andican ilinin Kurgan Tepe ilçesinin Savay kasabasına yerleştirildiler. Sürgün olunan halkın yerine Borcomi, Zestaponi, Saçxere ve Raça'dan gelen halk yerleştirdiler (URL-8). Sakunetlilerin bir kısmı 1958 yılında ilk önce Azerbaycanın Akstafa ilçesinin Büyük Kesik yerleşim yerine göç ettiler. Oradan da aynı yıl yine Azerbaycan'ın Sabirabat ilçesine geldiler ve burada Ahıska isminde köy kurdular. Bu köyde Gulogil, Kahigil, Kindelegil, Adalogil, Gogonadzeler, Yordanagil, Petrekgil, Kapitsgil, Culfagil, Arkigil, Rasogil, Karsligil, Potshoragil sülelelerinden olanlar yaşarlardı.

\section{Aile Adları ve Sülaleler}

1595 tarihli tahrir defterinde hane reislerinin adları, bazen sülale isimleri, bazen lakapları, bazen millî aidiyeti ve çoğunlukla babalarının isimleri ile birlikte, bazen de bunların hiç biri olmadan şahsın adı ve lakabı ile kayıt altına alınmıştır. Sakuneti köyünde bazen baba adları, bazen kendisinden öncekine işaretle "veled-i o" (onun oğlu), bazen "bin" ("oğlu"),"birâder-i o", bazen de lakap kullanılmıştır. Örnek; Leşkere Veled-i Zakire, Simon Veled-i Marinda, Varzel veled-o, Ağdgomel veled-i Novruza, Madagül birâder-i o, Mehmed bin Abdullah, Giorgi keşiş gibi.

1595 tarihli tahrir defterinde Sakuneti köyü, Azğur Nahiyesi'nin 9. Sırasında"Karye-i Sakunet tâbi'-i m.[ezbur] şeklinde yer almaktadır. Kayıtlarda aile reisinin adı ve baba adı zikrolunmuştur. Burada aile reisinin erkek olduğu görülmektedir. 1595 tarihli tahrir defterinde hane reislerinin ismi Tablo 1'de günümüz Türkçesinde transkripti verilmiştir.

Tablo 1. 1595 Yılında Sakuneti Köyü'ndeki Hâne Reisleri

\begin{tabular}{|l|l|l|l|}
\hline Leşkere veled-i Zakira & Madagülbirâder-i o & Mihran veled-i Ğvinia & Sabiya birâder-i o \\
\hline Simon veled-i Marinda & Vikri veled-i Mehrebil & İvane veled-i Varzel & İlyazveled-i o \\
\hline Varzel veled-i o & Elisa veled-i Abesalom & Gogiça veled-i Yusib & \\
\hline $\begin{array}{l}\text { Ağdgomel veled-i } \\
\text { Novruza }\end{array}$ & Revaza veled-i o & Abitar veled-i Yordan & \\
\hline
\end{tabular}

Kaynak: TTD, 1003 / 1595: 52; Cikia, 1947: 91-92.

1944 sürgünü öncesi Sakuneti köyünde yaşayan sülaleler ve Çahalov Nüsrettin tarafindan detaylı olarak düzenlenen bazı nüfus bilgiler Tablo 1'de verilmiştir (Tablo 2).

Tablo 2: 1941-1944 Y1lları Sakunet Köyü’nün Nüfus Bilgileri

\begin{tabular}{|l|l|c|c|c|c|c|c|l|l|}
\hline No & Sülale & \multicolumn{2}{|c|}{1941} & $\begin{array}{c}1941- \\
50\end{array}$ & $\begin{array}{c}1939- \\
1944\end{array}$ & \multicolumn{3}{|c|}{$1941-45$ savaşına gidenler } \\
\hline & hane & nüfus & $\begin{array}{l}\text { Telef } \\
\text { olan } \\
\text { haneler }\end{array}$ & $\begin{array}{l}\text { Askere } \\
\text { Alınanlar }\end{array}$ & $\begin{array}{l}\text { Şehit } \\
\text { olan }\end{array}$ & yaralanan & $\begin{array}{l}\text { Hasta } \\
\text { dönenler }\end{array}$ & $\begin{array}{l}\text { Sağ } \\
\text { dönenler }\end{array}$ \\
\hline 1 & Yordanagil & 33 & 153 & 3 & 29 & 11 & 9 & 1 & 8 \\
\hline 2 & Potsveragil & 14 & 59 & 1 & 12 & 6 & 7 & - & 4 \\
\hline
\end{tabular}




\begin{tabular}{|l|l|c|c|c|c|c|c|c|c|}
\hline 3 & Kapitsgil & 13 & 48 & 7 & 14 & 9 & 3 & 1 & 1 \\
\hline 4 & Kakhigil & 13 & 61 & 3 & 12 & 3 & 5 & - & 4 \\
\hline 5 & Adalogil & 10 & 38 & 1 & 7 & 3 & 1 & - & 3 \\
\hline 6 & Petrekgil & 10 & 43 & 2 & 7 & 6 & 1 & - & - \\
\hline 7 & Kindelegil & 9 & 39 & 4 & 6 & 3 & 2 & & 1 \\
\hline 8 & Karsligil & 9 & 42 & 5 & 8 & 6 & - & 1 & 1 \\
\hline 9 & Culfagil & 8 & 28 & 9 & 6 & 2 & 2 & 1 & 1 \\
\hline 10 & Mamigil & 7 & 25 & 3 & 5 & 3 & 2 & - & - \\
\hline 11 & Puturagil & 7 & 20 & 3 & 7 & 5 & 1 & - & 1 \\
\hline 12 & Bozavragil & 6 & 29 & 3 & 7 & 5 & 2 & - & - \\
\hline 13 & Goğonagil & 6 & 26 & 2 & 6 & 3 & 3 & - & - \\
\hline 14 & Çedlogil & 6 & 21 & 3 & 4 & 2 & - & - & 2 \\
\hline 15 & Kaşogil & 6 & 25 & 1 & 4 & 2 & - & 1 & - \\
\hline 16 & Bozadzegil & 5 & 17 & 2 & 2 & 2 & - & - & - \\
\hline 17 & Gulogil & 5 & 20 & 2 & 2 & 1 & - & - & 1 \\
\hline 18 & Çonkagil & 5 & 20 & 1 & 2 & - & 2 & - & - \\
\hline 19 & Cavakhgil & 5 & 18 & 3 & 3 & 3 & - & - & - \\
\hline 20 & Bayrakhdargil & 5 & 19 & 1 & 2 & 2 & - & - & - \\
\hline 21 & Kolkisgil & 4 & 17 & 1 & 1 & - & 1 & - & - \\
\hline 22 & Saradzegil & 4 & 18 & 1 & 3 & 3 & - & - & - \\
\hline 23 & Rasogil & 4 & 18 & 1 & 4 & 1 & 1 & 1 & 1 \\
\hline 24 & Perkhangil & 3 & 14 & - & 1 & - & 1 & - & - \\
\hline 25 & Arkigil & 3 & 18 & - & 3 & - & 1 & - & 2 \\
\hline 26 & Galustagil & 3 & 15 & - & 3 & 1 & - & - & 2 \\
\hline & Şiddat ${ }^{4}$ & 1 & 2 & 1 & & & & & \\
\hline & Toplam & 204 & $853^{5}$ & $63^{6}$ & 93 & 82 & $44^{8}$ & 6 & 32 \\
\hline
\end{tabular}

Kaynak: Çakhalov Nüsrettin, 1968.

Galustagilden 70 yaşlı Bakhshi Galustov 1984 yılında doğduğu köyü Sakuneti ziyareti sırasında Agara köyünü geçtikten sonra karşıda görünün dağın ismini Ruget Dağı olduğunu

\footnotetext{
${ }^{4}$ Şiddat'ın Ne Olduğunu Bulamadım

${ }^{5}$ Hesaplamada 855 olarak yazılmıştır

${ }^{6}$ Hesaplamada 58 gitmiştir

${ }^{7}$ Hesaplamada 160 gitmiştir

${ }^{8}$ Hesaplamada 40 gitmiştir
} 
bildirmişti (URL-7. Galustov'nun 23.03.89 tarihli mektubu). Sakunet köyünün 14 Kasım 1944 yılına kadarki yerleşimi tablo 11'de verilmiştir.

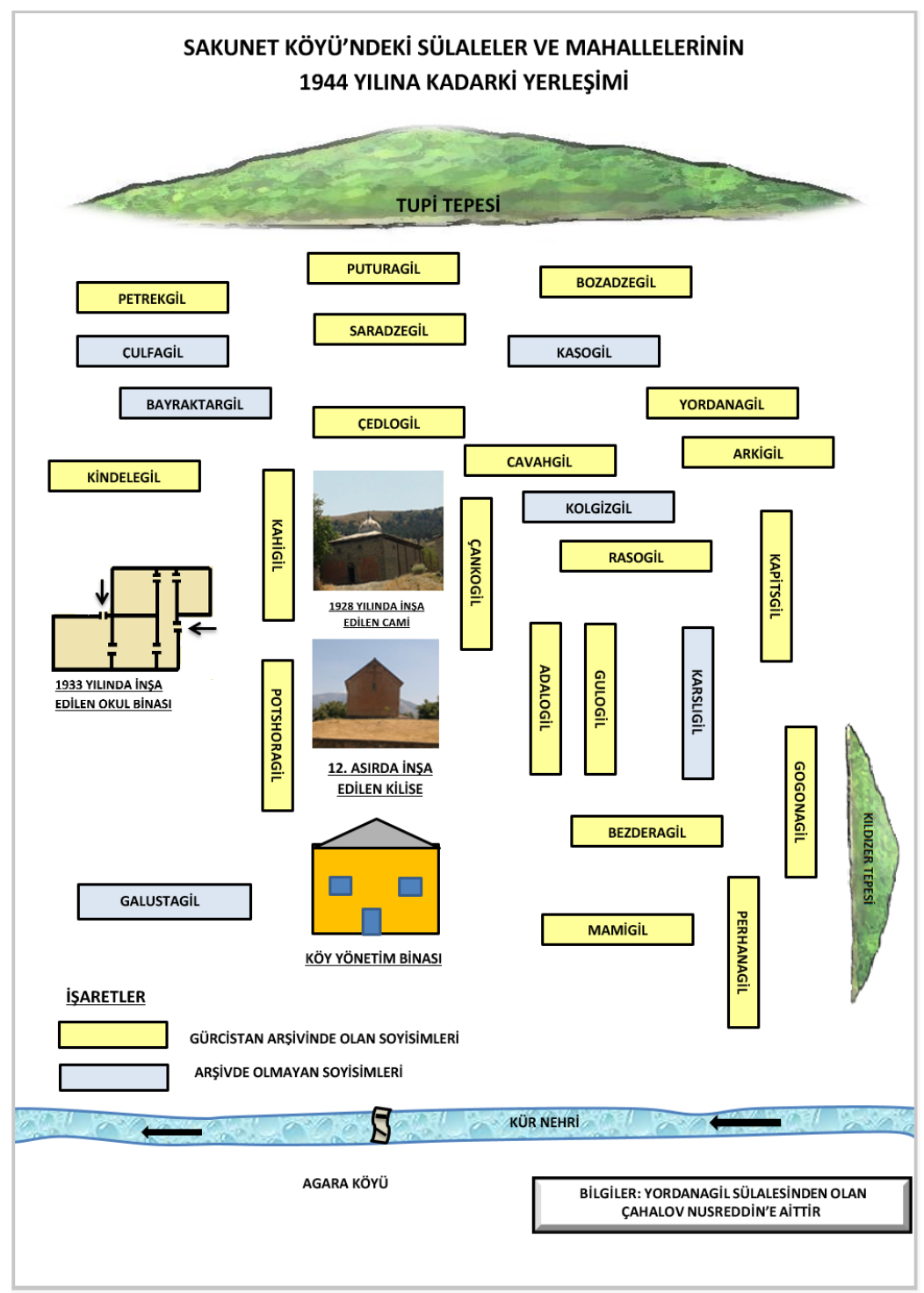

Resim 11: Sakuneti Köyü’ndeki Sülale ve Mahallelerinin 1944 Yılına Kadarki Yerleşimi

Yordanagil $^{9}$ Sakuneti köyünün en büyük ve en eski sülalelerinden olup bu sülale hakkında 1595 tarihli tahrir defterinde de rastlamaktayı. Yordan eskiden kullanılan ve sonralar unutulan erkek isimlerindendir. Yordanagil sülalesi Sakuneti'den başka Çıldır, nâm-1 diğer Ahıska Ey'aleti’nin 36 köyünde de ikamet etmekteydiler (Tablo 3).

${ }^{9}$ Gil burada ve genelde Ahıska'lılarda soyadını bildiren bir ektir. Aynı zamanda sülaleyi bildirir 
Tablo 3: 1595 Yılında Yordanagil Sülalesinin Çıldır Eyâleti’ndeki Dağlımı

\begin{tabular}{|c|c|c|c|c|c|}
\hline \multirow[t]{2}{*}{ Sülale } & \multirow[t]{2}{*}{ Sancak } & \multirow[t]{2}{*}{ Nahiye } & \multirow[t]{2}{*}{ Köy } & \multicolumn{2}{|c|}{$\begin{array}{c}1595 \text { Tarihli Defter } \\
\text { Sayfa No }\end{array}$} \\
\hline & & & & 1947 & TTD \\
\hline \multirow[t]{29}{*}{ Yordanagil } & \multirow{13}{*}{ Ahıska } & Güney & Tskrut & 22 & 16 \\
\hline & & \multirow{2}{*}{ Kuzay } & Shvlis-i Ülya & 37 & 24 \\
\hline & & & Corahet & 47 & 29 \\
\hline & & \multirow{2}{*}{ Ude } & Çobaşen & 70 & 40 \\
\hline & & & Kortohet & 75 & 43 \\
\hline & & \multirow{2}{*}{ Kvablian } & Apiyet-i Büzürg & 83 & 48 \\
\hline & & & Çala & 85 & 48 \\
\hline & & \multirow{3}{*}{ Azğur } & Sakuneti & 91 & 52 \\
\hline & & & Moksev & 94 & 53 \\
\hline & & & Slesa & 105 & 59 \\
\hline & & Altunkale & Smada-i Küçük & 110 & 62 \\
\hline & & Otskhe & Rabat Kale-i Otskhe & 118 & 67 \\
\hline & & Çeçerek & Puğa & 156 & 87 \\
\hline & Çıldır & Kenarbel & Vardisuban & 293 & 155 \\
\hline & \multirow{6}{*}{ Posof } & \multirow{4}{*}{ Güney } & Papala & 310 & 164 \\
\hline & & & Çvantel & 311 & 165 \\
\hline & & & Sakala & 314 & 166 \\
\hline & & & Saikhve-i Ülya & 315 & 166 \\
\hline & & \multirow{2}{*}{ Kuzay } & Cağisman & 320 & 169 \\
\hline & & & Husman & 326 & 172 \\
\hline & Penek & Panaskert & Gesmali & 383 & 246 \\
\hline & \multirow{8}{*}{$\begin{array}{l}\text { Büyük } \\
\text { Ardahan }\end{array}$} & \multirow{6}{*}{ Güney } & Siskvilishevi & 415 & 185 \\
\hline & & & Mağarkara & 416 & 185 \\
\hline & & & Pahrel & 420 & 187 \\
\hline & & & Rabat-i Kinzodamal & 420 & 188 \\
\hline & & & Dedegül & 436 & 194 \\
\hline & & & Torishev-i Veset & 438 & 195 \\
\hline & & Kuzay & Burdosan-i Küçük & 468 & 207 \\
\hline & & Meşe & Duduna & 473 & 209 \\
\hline
\end{tabular}




\begin{tabular}{|c|c|c|c|c|c|}
\hline & & & Veli & 475 & 210 \\
\hline & & & $\mathrm{Ur}$ & 478 & 211 \\
\hline & & & Ahalşen & 480 & 212 \\
\hline & & & İskareb & 488 & 215 \\
\hline & & & Harosman & 501 & 221 \\
\hline & & & Orezak & 503 & 222 \\
\hline & & & Karkatval & 503 & 222 \\
\hline & & & Burdosan-i Büzürg & 511 & 225 \\
\hline \multirow{4}{*}{ Cavahgil } & Panak & Penek & Karkul & 363 & 238 \\
\hline & \multirow{3}{*}{$\begin{array}{l}\text { Büyük } \\
\text { Ardahan }\end{array}$} & \multirow{2}{*}{ Güney } & Kanardid & 434 & 193 \\
\hline & & & Sarzab & 446 & 198 \\
\hline & & Meşe & Burdosan-i Büzürg & 511 & 225 \\
\hline Poshveradzegil & Ahiska & Ude & Lelovan & 60 & 35 \\
\hline
\end{tabular}

Kaynak: TTD, 1003 / 1595: 16-225; Cikia, 1947: 22-511.

Sakuneti Köyü en eski sülalerinden Cavahgil ve Potskhveragil’e de tahrir kayıtlarında görülmektedir (Tablo 2).

Cavakhgiller kendilerinin Javakheti'den, Kindelehiller ise Kilda Köyü'nden Sakuneti'ye göç ettiklerini bildirmektedirler (URL-24). Karsligil Kars'tan, Arkigilin de Arkissikhe'den gelip Sakuneti köyüne yerleştikleri söylenmektedirler. Gulogil sülalesinden iki aile Ardanuç ilçesinin eski adı Göreşet olan Kutlu Köyü’ne köyüne yerleşmişlerdir. Onlar şu Bilgin soyadını taşımakta olup, Ardanuç, Rize ve Bursa'da ikamet etmektedirler.

Günümüzde, Sakuneti'de Betiaşvili (URL-15), Buhrikidze (URL-16), Tabunidze (URL-17), Tikanaşvili (URL-18), Kojoridze (URL-19), Kukçişvili (URL-20), Gelaşvili ve başkaları yaşamaktadır.

\section{Sakuneti Köyü'nde Köprü Vakfı "Hayır Köprüsü”"}

Samtskhe-Saatabago Bölgesi'nde 1579 yılından sonra Çıldır Eyâleti kurulduktan sonra vakıf çalışmalarına önem verilmişti. Ve bu da devlet tarafından desteklenirdi. 1595 tarihli tahrir defterinde Ahıska Sancağı Güney Nahiyesi Ahıska Kasabası "Cam-i Şerif Vakfı" (TTD, 1003 [1595] 130: 22, 32), Kuzay Nahiyesi "Köprü Vakfı" (TTD, 1003 [1595] 130: 27), Ude Nahiyesi Ude Rabat Kalesi Mescid-i Şerif "Kur'an-1 Azim Kıraat-1 Vakfi", Ahıska Sancağı Altunkal'a Nahiyesi Çule Kilisesi vakfı (TTD, 1003 [1595] -130: 63), Hertvis Sancağı Hertvis Nahiyesi Bnela Köyü’ndeki "Vakf-1 Hacı" olarak bilinen Hacı Vakfı (TTD, 1003 [1595] : 130: 100) ve bir çokları hakkında bilgi verilmektedir. Çıldır Beylerbeyi Hızır Paşa'ya ait Köprü Vakfı Ahıska Sancağı'nın Kuzay Nahiyesi’nin Küçük Merek Köyü'nde yerleşmekteydi. Köprü vakfı Müslüm ve gayrimüslümlerin ortaklaşa desteklendiğini defter kayıtlarından görmekteyiz. Şöyleki vakfın gelir kaynağını Ali Paşa'nın iki hisse, Mlaşhev Köyü'ndeki bir hisse bağları ve Mlaşhev Köyü’ndeki 10 kilelik zemin tarlası, İvane'nin iki kıt'a tarlası ve ve Mazğver keşişin bağları teşkil etmektedir. Vakıf tutanaklarında 100 akçelik kira bedeli ödendikten sonra geri kalan kısmı köprü masraflarına sarf olunmaktadı (TTD, 1003 [1595] 130: 27). Köprüler büyük önem arz 
etmekteydi. Çıldır Sancağı'nın Kinarin Nahiyesi Oloda köyünün batısında Kür nehri üzerindeki köprü Gürcistan, Zernişad ve Kars’1 birleştirmektedir. Bu köprünün ticari önemi büyük olduğundanonun korunması ve onarımı Ooloda köyü halkı tarafından sağlanırdı. Bu yüzden köy halkı da tekâlif-i örfiyeden muaf tutulmuştu. Bu durum da gelecekte yeni Defter-i Hakani'de kaydı şerh olunmuştu (TTD, 1003 [1595] 130: 152). Büyük Ardahan Sancağı Kuzay Nahiyesi'nin Kutar Melik karyesinde köprü yapım ve onarımlarıdan bahsedilmektedir. Erzurum, Ardahan ve Ahıska yolları üzerinde olan Ardahan Kal'ası yakınlığındaki köprülerin yapım ve onarım hizmetleri Kutar Melik köy ahalisine verilmiş ve köy halkı da bunun karşılığında tekalif vergilerinden muaf tutulmuştu (TTD, 1003 [1595] 130: 201).

Köprü Vakfı Eyâlette bir gelenek haline geldiği daha sonralarda da görülmektedir. Her ne kadar vakıfları devlet desteklese de şahıslar tarafından da bu hayır kurumunun faaliyet gösterdiği bilinmektedir. Sakuneti köyündeki Şakir dedenin "Hayır Köprüsü” (Hayır Vakfi) bunun bir örneğidir. Bu köprü Sakuneti ile Kvaltakhevi (Koltahev) köyleri arasındabulunan dere üzerinde kurulmuş ve halkın hizmetine sunulmuştu (Kişisel Görüşme: Hayrettin Keskin, 1945 Sakuneti doğumlu).

\section{Yüzyıl Sonlarında Sakuneti Köyündeki Ekonomik Faaliyetler}

Sakuneti Köyü, Akhaltsikh-Tbilisi ana yolunun $500 \mathrm{~m}$. sağ tarafında yer almaktadır. $\mathrm{Bu}$ husus onun ticari hayatta önemini artırmaktadır. 1595 tarihli tahrir defteri 1şığında köyün ekonomik yapısını incelediğimizde XVI. yüzyıl sonlarında köyde tarım, hayvancılık ve bağcılığın yapıldığ 1 görülmektedir. Ziraatın temelinde hane reisi erkeğin simgelendiği köylü ailesi olduğu bilinmektedir (İnalcık, 1993: 2).

1595 tarihli tahrir defterinin başına eklenen kısa kanunnâme, vergilendirmenin ana yönlerini içermektedir. Sakuneti Köyü’nün vergi kalemleri 1595 TTD’nin 52. ve Cikia'nın 1947 yılında Osmanlıca yayınladığı kitabın 91-92. sayfalarında yer almaktadır. Köyün ekonomik yapısını incelemek için bu bilgiler büyük önem arzetmekte olup onların günümüz Türkçesindeki karşılığını tablo halinde çalışmamıza eklenmiştir (EK: 1).

\section{Sakuneti Köyü’ndeki Vergi Kalemleri ve Miktarları}

1003 / 1595 tarihli TTD’nin 52. ve Cikia’nın 1947 yılında Osmanlıca yayınladığı kitabının 91-92. sayfalarında Sakuneti Köyü’nün “karye-i Sakunet tâbi-i m.” adı altında tahrir dökümü verilmiştir. İlk önce köydeki hane reisleri hakkında bilgi verilmiş daha sonra toplam 12.400 akçe olan köyün hasılatı belirtilmiştir. Bundan sonra vergi kalemleri hakkında bilgi verilmiştir. Vergi kalemlerinden sonra şer'i mahkeme kararının bir hisse bağın kiralanması hakkında hükmü kaydedilmiştir. Aşağıda bu bilgilerin TTD ve Cikia kitabındakı bilgiler ve onların tarafımızdan yapılmış transkripti günümüz Türkçesinde çalışmamıza eklenmiştir (Tablo 4).

Tablo 4. Sakuneti Köyü Vergi Kalemleri ve Miktarları

\begin{tabular}{|l|c|c|l|c|}
\hline \multicolumn{1}{|c|}{ [Vergi Kalemleri] } & Kile & $\begin{array}{c}\text { Kiymet } \\
{[\text { akçe] }}\end{array}$ & \multicolumn{1}{|c|}{ [Vergi Kalemleri] } & $\begin{array}{c}\text { Kiy } \\
\text { met } \\
{\left[\begin{array}{c}\text { akç } \\
\text { e] }\end{array}\right.}\end{array}$ \\
\hline İspenç, 14 nefer & & 350 & Resm-i âdet-i ağnâm & 300 \\
\hline Hinta & 300 & 3600 & Şıra,150 men & 1200 \\
\hline
\end{tabular}




\begin{tabular}{|l|c|c|l|c|}
\hline Şa'ir & 400 & 4000 & Resm-i hınzır & 200 \\
\hline Çavdar & 30 & 300 & Resm-i kevvâre & 200 \\
\hline Erzen & 20 & 200 & Resm-i bostân & 250 \\
\hline Nohut & $4^{10}$ & 120 & Resm-i tapû ve deştbâni & 200 \\
\hline Mercimek & 5 & 100 & Resm-i murahhasiye be her hâne-i fi 2 & 28 \\
\hline Bakla & 4 & 60 & Resm-i yaylak & 250 \\
\hline Zeğrek & 10 & 100 & Resm-i yatak & 120 \\
\hline Resm-i meyve & & 200 & Bâd-i havâ ve resm-i arûs & 132 \\
\hline Resm-i yonca ve giyâh & & 350 & Asiyâb, 2 bâb, sene-i kamila ${ }^{11}$ & 120 \\
\hline
\end{tabular}

Bağ-i Giorgi Keşiş ve karındaşı Mehrebil 1 kıt'a hala der tasarruf-1 Mehmed bin Abdullah ber mûceb-i hüccet-i şer'iyye ber vech-i maktu'a fi sene 20 .

Kaynak: TTD, 1003 / 1595: 52; Cikia, 1947: 91: 92.

\section{Üretimi Yapılan Tarım Ürünleri ve Bunlardan Alınan Vergiler Sakuneti Köyü'nde Ziraî Üretim}

XVI-XVII. yüzyıllarda, nüfusun çoğunluğu köylerde yaşamakta olup geçimini tarım ve hayvancılıkla sağlamaktaydı (Ünal, 1989: 64). Ziraatın temel emek birimi, hane reisi erkeğin simgelediği köylü ailesidir (İnalcık, 1993: 1-14). Ayrıca kazanç ve vergi sağlayan hane reisi nüfus tespitlerinde de önem arz etmekteydi. Bekârlar da vergilendirildiğinden tahrir defterlerinde "mücerred" olarak kayıt altına alınmışlardır (Sahillioğlu, 1991: 108109).

Kür boyu köyleri Samtskhe-Cavakheti’nin en önemli ziraat sahalarını teşkil etmektedir. $\mathrm{Bu}$ durum, Kür boyu köylerinin her zaman ziraî hayatın vazgeçilmez alanlarını oluşturmaktadır. Kür Nehri'nin sağ tarafında yerleşen Sakuneti Köyü'nün iklimi ve coğrafi özelliği ziraî üretiminde büyük önem taşımaktadır. Köyün iklimi burada birçok ürünün yetiştirilmesine imkân sağlamaktadır. Kür Nehri ve ondan ayrılan arklar,Orpola ve Blorza köylerinden gelen Elasur suyu, Koltakhevi köyü yakınlarındaki Sakrolan ve Solatkhevi dereleri sayesinde köy ekinleri sulanmaktaydı. Tepelik alanlar yağmurla sulanmaktaydı.

Sakuneti Köyü'nde tarla, bağ ve bahçelerde üretilip vergiye tabi tutulan ürünler buğday, arpa, çavdar, erzen, mercimek, nohut, bakla, şıradır. Tahrir defterlerinde vergiye tabi olan ürünlerin birim fiyatları da belirtilmektedir. Bu durumda akçe olarak belirtilen vergi bedelinin, ağırlık veya haim olarak belirtilen vergi miktarına bölünmesi ile ürünün birim fiyatları belirlenmektedir. Buna göre, 1595 tarihli tahrir defterine göre ürünlerin birim fiyatı tablo 5'de olduğu gibidir. Kayıtlarda meyvenin birim fiyatı verilmemiştir. Sadece kanunname gereğince diğer ürünlerde olduğu gibi \% 5 oranındakı öşür bedeli belirtilmiştir. $\mathrm{Bu}$ yüzdendir $\mathrm{ki}$, bu ürünün toplam üretim değeri hesaplanabilmekte, fakat üretim miktarının belirlenmesi mümkün olmamaktadır. Ayrıca halk kendi ihtiyaçları için patates,

${ }^{10}$ Orjinalda 4, Cikia'da 3 matbaa hatası olarak yazılmıştır. Zira metnin gürcüce tercümesinde orijinalda olduğu gibi 4 yazılmıştır (Cikia, 1941: 94).

${ }^{11}$ Kamila-Tam Y1l 
lahana gibi ürünlerin de yetiştirdiği muhtemeldir. Meyve çeşitlerinden elma, armut, kiraz, şeftalı, meshlere ait üzüm gibi çeşitli meyveler de yetiştirilmekteydi.

\section{Hububat ve Bakliyat}

Sakuneti'nin ait olduğu Azğur nahiyesinde ziraî üretimin temelini hububat ürünleri teşkil etmektedir. Diğer vergilere oranı en yüksek olan vergi biriminin de hububattan alınan vergiler meydana getirmektedir. Sakuneti köyünde yetiştirilen hububat ürünleri şunlardır: "hınta", "şa'ir", “çavdar" ve "erzen”. Bunların her birinden hububat öşrü alınmaktaydı. Osmanlının ilk zamanlarında şer’i hüküm gereğince onda bir vergi alındığına göre öşür kelimesi kullanılmıştır (Pakalın, 1952: 746).Fakat Gürcistân Vilâyeti’nde bu 1/5 miktarında olmuştur (Akgündüz, 1994a : 579).

Sakuneti köyü'nün en önemli ürünü hiç şüphesiz hububattır. Hububat içerisnde hınta (buğday) ve şa'ir (arpa) ilk sıradadır. Onları çavdar ve erzen takip etmektedir. Hububatın yanı sıra, köyde sanayi bitkisi olan zeğrek de yetiştirilmekteydi. Ayrıca köyde nohut, mercimek ve bakla gibi bakliyat türlerinin üretimi yapılmaktadır.

1595 tarihli tahrir defterinde köyde yetiştirilen ürünler "Hasıll" başlığı altında kaydedilmiştir. Hasılın altında yetiştirilen ürün hınta (buğday), şa'ir (arpa), çavdar, erzen, nohut, mercimek, bakla, zeğrek çeşitleri, kile olarak ağırlığı ve akçe olarak vergisi hem aynı, hem de nakit olarak kaydedilmiştir. Ürünün miktarı ve değerinin birlikte zikr olunması, ürünün tahrir kıymeti hakkında bilgi edinmesine yardım etmektedir (Güçer, 1964: 58-59).Tahrir defterlerindeki ürünlerin fiyatı tahrir komisyonları tarafından belirleniyordu (Güçer, 1964: 58). Bü yüzden defter kayıtlarındakı tahrir kıymetleri resmi karakterde idi.

Buna göre Sakuneti köyünde üretimi yapılan hububat ve bakliyat çeşitlerinin kile olarak alınan kıymetleri buğday 12 akçe, arpa, çavdar ve zeğrek 10 akçe, nohut 30 akçe, mercimek 20 akçe, bakla 15 akçeydi (Tablo 5).

1595 tarihli tahrir defterini incelediğimiz zaman hububatın, özellikle buğday ve arpanın çok önem arzettiğini görebiliriz. Çavdar ve erzen bunları izlemektedir. Bakliyat türlerinden, nohut, mercimek ve bakla üretimi az da olsa Sakuneti köyünde yapılmaktaydı.

Bakla kazık köklü, yıllık bir bitkidir. Fasulyaya/Lobiyoya/benzer. Kökleri $110 \mathrm{sm}$ derinliğe kadar iner. Yan kökleri kuvvetli bir şekilde etrafa yayılır ve üzerlerinde yumrular meydana gelir. Tüysüz olan sapı bir metre kadar yükselebilir. Sap üzerinde sarmalı durumda yaprakları vardır. Çiçekleri yaprak koltuklarından çıkar. Çiçeklerin kendine has ve hoş bir kokusu vardır. Meyvesi, tohum araları bölmeli ve dolgun bir kapçıktır. Kapçık taze iken yeşil, olgunlaşınca esmerleşir ve sertleşir. Bakla, baklagillerdeki tüm sebzeler gibi bedenin kansere yakalanma riskini azaltır.

Hububat üretimi ve ondan alınan vergi Sakuneti köyünün en yüksek gelir kaynağını teşkil etmektedir. Gürcistân kanunnâmesi gereğince eyâlette üretimi yapılan ürünlerden alınan öşür miktarı humus, yani 1/5 nispetinde alınmaktadır (Akgündüz, 1994a : 578). Sakuneti köyünde yetiştirilen ürünün tam miktarını bulmak için ürünün öşür miktarını 5 ile çarpmak yeterlidir. Örnek, Sakuneti köyünden yıllık 300 kile buğday öşrü alınmaktadır. Bu durumda köyün gerçek buğday üretiminin 300 x $5=1.500$ kile olduğunu söylemek mümkündür. Gürcistân kanunnâmesinde kilenin kilogram karşılığ bilgi bulunmamadığndan o zaman başkent olan Iistanbul kilesini baz almayı uygun bulmaktayız. Bir İstanbul kilesi 25.659 kg. denk gelmektedir (İnalcık, 2000: 444).Hınz’a 
göre ticaret işlerinde buğdayla arpa farklılık göstermekteydi. Yapılan ticaret tartılarında buğday 25,656 kg, arpa ise $22.25 \mathrm{~kg}$ olarak işlem görmekteydi (Hınz, 1990: 51).

\section{Hububat ve Bakliyat Öşür Bedeli}

Sakuneti Köyü'nde hububat ve bakliyat içerisinde en fazla öşür bedeli arpadan sağlanmaktadır. Arpa öşür bedelini, üretimde ikinci sırada yer alan 3.600 akçesiyle buğday takip etmektedir. Bir kilenin yaklaşık $25,6 \mathrm{~kg}$ olduğunu göz önünde bulundurduğumuzda köyden elde edilen öşür miktarı $7.680 \mathrm{~kg}$ veya 7 ton $680 \mathrm{~kg}$ 'dır. Verginin $1 / 5$ nispetinde olduğundan köyde buğday üretimi 1.500 kile veya $38.400 \mathrm{~kg}$. Bu da 38 ton $400 \mathrm{~kg}$ 'dır. Daha sonra çavdar (30 kile veya 300 akçe), erzen (20 kile veya 200 akçe), mercimek (5 kile veya 100 akçe), nohut (4 kile veya 120 akçe), bakla (4 kile veya 60 akçe) sirasıyla gelmektedir. Sanayi bitkisi zeğrek (10 kile veya 100 akçe) hasıl olunan vergiler içerisinde yer almaktadır. Zeğrek hem gida, tedavi hem de aydınlatma ve isınma amaçlı kullanılmaktadır. Tohumları \% 40-45 yağ içeren zeyrektenbezir yağı elde edilmektedir. Bu yağ yemk yapımında kullanıldığı gibi boyacılıkta da kullanılmaktadır (Güneş, 1994: 160).

Köy nüfusu ile üretimi birbiri ile karşılaştırmakla yetiştirilen ürünlerin halkın geçinin için yeterli olup olmadığını tespit etmek mümkündür. Araştırmacı S. Faroqhi'ye göre XVI. yüzyılda bir köylünün besin ihtiyacı $300 \mathrm{~kg}$ tahıl gerekmektedir. Üretilen mahsülün 1/4 veya 1/3'inin tohumluk için ayırması gerekmekteydi (Faroqhi, 1993: 266-267). Köyde yetiştirilen ürünün $1 / 4$ ekin için ayırdıktan sonra geri kalanı vergi mükellefi olan hane sayısına böldüğümüzde kişi başına düşen miktarı hem kile, hem de $\mathrm{kg}$ olarak tespit edebiliriz. Şöyle ki, Sakuneti köyünde üretimi toplam 1.500 kile olan buğdayın 1/4'ni, yani 107 kileyi ekin için ayırdıktan ve öşür olarak ödenen 300 kileyi toplam üretimden çıktuktan sonra (1.500-407) 1093 kile köy halkının yıllık ekmek ihtiyacı için kullanılmaktadır. Bu miktarı köydeki haneye bölündükten sonra (1093: 14) her hane için 78,07 kile buğday teşkil etmektedir. Sakuneti köyünde her hanede 8 kişi olduğunu kabul edersek kişi başına bu 9.76 kiledir. Bunu da kg olarak belirlediğimizde (9.76 x 25.656) yaklaşık 250’yi bulmaktadır. $\mathrm{Bu}$ rakamdan görüldüğü gibi kişi başına olan $250 \mathrm{~kg}$ buğday halkın ekmek ihtiyacını tam karşılamamaktadır. Aradaki $50 \mathrm{~kg}$ eksikliği ekmek için kullanılan arpa ve erzenden (mısırdan) hazırlanan çadı (วł๖ৎ̧o), yani mısır ekmeği doldurmaktadır.

Arpa daha çok hayvan yemi olarak kullanılmaktadır. Arpanın buğdayla karıştırılmasıyla un da yapılmaktadır. Arpa tahrir defterinde “şa'ir”" olarak geçmektedir.

Buğday ve arpadan sonra üretim olarak 3. sırayı çavdar almaktadır. Çavdarın besin değeri pek fazla olmayıp elverişsiz topraklarda da yetiştirilmekteydi. Sakuneti Köyü'nde çavdar üretimi 150 kile kadardır $(30$ x $5=150)$.

Üretim olarak çavdarı erzen takip etmektedir. Erzen, darı, mısır anlamında kullanılmakta (Kurt, 2005 904) ve kilesi 10 akçeden işlem görmektedir. Sakuneti köyünde erzen mısır (lazut) olarak tanımlanmaktadır. Lâzut adlı ürüne, Trabzon sancağında 1486 tarihli kayıtlarda rastlanmış olup Akçâbad, Maçka ve Yomra nahiyelerinde ekildiği bilinmektedir (Bostan, 2002: 490). Erzen besin olarak buğdaydan geri kalan ekmek ihtiyacını tamamlamakta çok önemli yeri teşkil etmektedir. Zira lazuttan (mısırdan) hazırlanan ałsscoo (çadi, yani mısır ekmeği) bölge halkının en sevilen besin gıdası idi. Sakuneti Köyü'nde 1595 yılında üretilen erzenin (mısır olarak tanımlanan lazutun) üretim miktarı 100 kiledir ( 20 x 5=100).

\section{Yağlı Bitki Tarımı-Zeğrek}


İp, halat, urgan vs. yapımında kullanılan keten ve kendir, Akdeniz (Yörük, 2010: 8), Karadeniz kıyılarında Samsun ve Ordu'da, Ege'de, Güneydoğu'da ve Doğu'da Artvin (Bekadze, 2015: 126) coğrafyalarına has bir ürün olsa da Azğur Nahiyesi'nde de yetiştirilmekteydi. Zeğrek (keten) doğal, yani tabii bir elyaftır. Keten bitkinin saplarından toplanırdı. Arapça "kutan" derlerdi. İlk çağda pamuktan /pambıktan/ sonra kullanılan ham maddedir. Onun tohumları \% 40-45 yağ içermektedir. Bu yağ "Bezir yağı" olarak bilinmektedir. Ketenden yemeklik yağ alındığı gibi boyacılıkta kullanılan keten tohumu yağı da alınmakta idi (Güneş, 1994: 160). Yağı alındıktan sonra tohumların geri kalan atığ1 hayvan yemi olarak kullanılmakta idi. Tahrir defterinde bu verginin adı "zeğrek" olarak geçmektedir. Kanunnâmede ketende 1/10 oranında öşür alınmak öngörülmüştü (Akgündüz, 1994a: 579). Sakuneti köyünde üretilen zeğrekten 10 kile, yani $256 \mathrm{~kg}$ vergi alınıyodu ki, bunun da o zamanki tahrir değeri 100 akçe idi (TTD, 1003 / 1595: 52; Cikia, 1947: 91-92). Zeğrekle ilgili tahrir dökümüne baktığımızda bir kile zeğreğin fiyatı Ahıska Sancağı'nda 10 akçe, Hertvis, Ahalkalak, Çıldır ve Posof sancaklarında ise 8 akçe idi. Ahıska Sancağ1 Azğur Nahiyesi'ne bağlı Sakuneti köyü kayıtlarında bir kile zeğreğin narh fiyatının 10 akçe olduğu tahrir kayıtlarında görülmektedir (TTD, 1003 / 1595: 52; Cikia, 1947: 91-92).

\section{Bağ, Bahçe ve Bostân Ziratı}

Samtskhe Bölgesi bağ, bahçe ve bostan ziraatının tarihi çok eskilere dayanmaktadır. Zira buranın iklim şartları her türlü meyve ve sebzenin yetiştirilmesini sağlamaktadır. Tahrir kayıtlarından görüldüğü gibi Sakuneti köyünde "şıra" vergisi adı altında bağcılığın, "resm-i meyve" adı altında bahçeciliğin, "resm-i bostân" adı altında da bostân ürünlerinin yetiştirildiği görülmektedir. Üzüm bağları Sakuneti Köyü’ne süs katmaktaydı. Bu köyde üzümden hasıl edilen şıra miktarı öşür olarak 150 men idi. Bunun da tahrir değeri 1200 akçe idi. Gürcistân kanunnâmesi gereğince 1/5 vergi alındığına göre köyde şıra üretimi 750 men $(150 \times 5)$ idi.

XVI. yüzyıl sonlarında Sakuneti köyünde en çok üretimi yapılan hububatın dışında meyve ve bostan ürünleri yetiştirilmekteydi. Devlet, bağ, bahçe ve bostan ürünlerinin üretiminden bu ürünlerin satılık için Pazara götürüldüğü zaman vergi almaktaydı. Köylünün kendi ihtiyacı için evinin yakınlığındaki bahçesinde ve tarlasında üretülen ürünlerden vergi alınmazdı. Osmanlı kanunnamelerinde bu şöyle zikrolunmaktadır:“....sebzeden ve meyveden kendi maişetleri için olmayub, bazara getürüb satılursa, sahib-i arza defterde öşr-i bostan ve meyve hasıl kaydolunan öşr-i sebze ve meyve alınur...(Solak, 2008: 220). Defterr kayıtlarından görüldüğü gibi, Sakuneti köyünden "resm-i meyve" olarak 200 akçe vergi alınmaktadır. Kayıtlardan hangi meyve çeşitleri olduğu kesin bilinmemektedir. Köy bağlı bahçeli yer olduğundan köyde çançur, elma, armut, kayısı, böğürtlen, erik, dut, incir ceviz, şeftalı, vişne ve s. yetiştirildiğini söylemek mümkündür.

\section{Meyve Üretimi}

Meyve fars dilinde, mive kelimesinden türemiş olup yemiş, ürün, meyva anlamlarını ifade etmektedir (Parlatır, 2011: 1084). Gerek Osmanlı Devrinde, gerekse de günümüzde meyve elma, armut, kaysı ve diğer ürünlerin ortak adı olarak kullanılmaktafır. Meyve vergisiyle ilgili Gürcistan'la ilgili kanunnâmelerde her hangi bir kayıt bulunmamaktadır. Fakat Fatih Devri kanunnâmelerinde "yemişten ve meyveçeden onda bir alına" şerhine rastlanmaktadır (Akgündüz, 2006: 353). Sakuneti köyünden meyveden yıllık elde edilen gelir 200 akçe olmuştur (TTD, 1003 (1595): 52; Cikia, 1947: 91). 
Sakuneti köyünde yetiştirilen meyve çeşitlerinden halkın pekmez, pestil ve diğer tatlı ihtiyaçları karşılanmaktaydı. Süt elması, Şah elma, Söbe elması, Çançur, Panta bölgenin en yaygın meyve çeşitlerindendir. Şah elma yalnız bu bölgeye ait meyve olup ortalama yılda $300 \mathrm{~kg}$ 'dan fazla ürün vermekteydi (URL-22). Süt elması da Akhaltsikh bölgesine ait olup başka yerlerde yetişmemektedir. Süt elmasının yıllık ürünü $250 \mathrm{~km}$ idi. Köyün en ünlü elma çeşidi Söbe elmasıydı. Bunun yıllık ürünü 100-150 kg kadard1.

Armutlara gelince en çok sevilen "Nene armudu"ydu. Bunun da yıllık miktarı ortalama $250 \mathrm{~kg}$ kadardı. $600 \mathrm{~kg}$ toplanan ağaçlar da vardı.

\section{Ceviz}

Ceviz Arapça bir kelime olup kalın gövdeli, uzun ömürlü ve ahşabı değerli olan bir bitki ve onun "koz" denilen meyvesidir (Parlatır, 2011: 250). Bölge her zaman cevizi ile ünlü olmuştur. Sakuneti köyünde cevizden ya meyve adı altında vergi alınmış, ya da yeterince üretim olmadığından vergi alınmazdı. Ceviz ancak yerli halkın ihtiyaçlarını karşılamaktaydi.

\section{Resm-i bostân}

Sakuneti köyünde "resm-i bostân" adı altında 250 akçe vergi alınmaktadır. Kayıtlardan bostân ürünlerinin çeşitleri hakkında her hangi bir bilgi bulunmamaktadır. Fakat köy halkının ihtiyaçları gereğince lahana, havuç, patlıcan, pancar, kabak, karpuz, salatalık, turp, soğan, fasulye ve s. olduğu hakkında fikir söylememiz mümkündür. Gürcistân kanunnamesinde bostan vergisi ile ilgili madde bulunmamaktadır.

\section{Bağcılık}

Sakuneti köyünde bağcılık, hububat ziraatinden sonra en önemli faaliyet alanlarındandır. Zira köyün toprak yapısı bağcılığın yapılmasını sağlamaktadır. Üzüm nehir kenarlarında yetiştirildiği gibi dağlık alanlarda teraslarda da yetiştirilmekteydi. Bu bölge yalnız Gürcistân'da değil tüm dünyada dağlık alanda üzüm yetiştirilmende ilk sıradadır. Sakuneti köyünün bağlı bulunduğu Azğur Nahiyesi'nde üzümün kalite farklılığı bölgenin rakımına bağlı olmuştur. Azğur, Orpola, Blorza, Hideti, Tkemlovana, Sakuneti, Sinuban, Giorgisminda, Zurzana ve Agara. Bu köylerin rakımlığına bakıldığında yetiştirilen üzüm bağları 900-1700 m . yükseklik yerlerdedir. Azğur Nahiyesi’nde yetiştirilen üzümün kalite farkı şu şekildedir:

1. Rakımı 900-1000 m.olan Azğur, Mugaret, Sakunet, Tkemlovana, Sinuban köylerinde yetiştirilen üzüm.

2. Rakımı 1000-1200 m.olan Persa köyünde yetiştirilen üzüm

Bağcılık Samtskhe'nin bazı köyleri hariç tüm bölgede yetiştirilmektedir.

Gerek Sakunet köyünde gerekse de tüm bölgede üzümden şıra (şarap) yapılmaktadır. Ayrıca bundan pekmez de yapılmaktadır. Köyden verginin üzümden değil üzümden elde edilen şıradan alındığı görülmektedir (Solak, 2008: 226). Gürcistân'la ilgili kanunnamelerde şarapla ilgili her hangi bir hüküm bulunmamaktadır. Kanunâmede yalnız bağdan behre alındığı görülmektedir (Akgündüz, 1994a: 579). Fakat “İnoz Kazası Kanunnâmesi'nin 5. ve 7. maddelerinde, Trabzon Sancağı'nın 9. maddesinde, Selânik Kazası Kanunnâmesi'nin 8. maddesinde şarap alım-satımı ile ilgili hükümler bulunmaktadır (Iasha Bekadze, 2015: 125). Amid Sancağı Kanunnâmesi'nde ise şarap getirmenin yasaklandığına ve getiren kişinin de cezalandırıldığına dair kayıt bulunmaktadır (Barkan, 2001: 138). Tahrir kayıtlarından da görüldüğü gibi şıradan alınan ağırlık vergisi Çıldır Eyâleti'nde men ağırlık ölçü birimi olarak kullanılmaktadır. Sakuneti köyünde şıradan elde 
edilen hasılât 150 men olup bunun da parasal değeri 1200 akçedir. Bu bilgiden hareket ederek bir men şıranın 8 akçe olduğunu söyleye biliriz. Macaristan'da ise şarap, daha doğrusu şıra öşrü ölçüsü olarak, Macarca cseber (çeber=bir çeşit kap) kullanılmakta olup yaklaşık 42,42 litreye denk gelmekteydi (Geza Dâvıd, 1999: 124). Gayrimüslimlerin üzümden şıra (şarap) hazırlanması pekiyi karşılanmadığı üzümün kurutulması ve ondan pekmez turşu yapılması istenilmiştir (Solak, 2008: 227).

\section{Tahrire Göre Sakuneti Köyündeki Bazı Ürünlerin Narh Fiyatları}

Narh, âzami fiyât mânasında kullanılan bir terim olup (Palalın, 1952: 654) mufassal tahrir defterlerinde buğday, arpa, çavdar, erzen, nohut, mercimek, bakla, zeyrek, şıra ve s. gibi ürünlerin padişah huzurunda belirlenen değeridir (Yörük, 2002: 137). 1595 tarihli tahrir defterinde, Sakuneti köyünde nakdî olarak vergiler akçe olarak da kaydedilmiştir. Yani buğday, arpa, erzen, zeğrek, şıra, nohut, mercimek, bakla vs. gibi ürünlerin belli bir narh üzerinden akçe olarak değeri verildiğine göre Sakuneti köyündeki bazı ürünlerin fiyatlarını tespit edebilmekteyiz. $\mathrm{Bu}$ fiyatlar tahrir yapıldı̆̆ belirleniyor ve padişahın onayından sonra kesinlik kazanıyordu. Tahrir emînleri fiyatı belirlerken ürünün önceki üç yıllık ortalamasını akçe olarak belirlemekte ve bölge kadısından aldıkları mahallî narhı gösteren hüccetleri de ekleyip, merkeze padişahın onayına göndermekteydiler. Belirlenen fiyatlar padişah onayladıktan sonra kesinleşir (Barkan, 1941: 40) ve tahrir defterlerine kaydolunurdu.

1595 tarihinde Sakuneti Köyü'ndeki bazı ürünlerin fiyatları tahrir defteri verilerine göre tespit edilerek tablo 5'de gösterilmiştir.

Tablo 5: Sakuneti Köyü'ndeki Bazı Ürünlerin 1 Kilesinin ve 1 Men’in Tahrir Kiymetleri

\begin{tabular}{|l|c|c|c|c|}
\hline Ürünün çeşitleri & Kile & Kiymeti, akçe & $\mathrm{kg}$ & Kiymeti, akçe \\
\hline Hınta /Buğday/ & 1 & 12 & 1 & 0,47 \\
\hline Şair/Arpa/ & 1 & 10 & 1 & 0,39 \\
\hline Çavdar & 1 & 10 & 1 & 0,39 \\
\hline Erzen /Dar1/ & 1 & 10 & 1 & 0,39 \\
\hline Nohut & 1 & 30 & 1 & 1,17 \\
\hline Mercimek & 1 & 20 & 1 & 0,78 \\
\hline Bakla & 1 & 15 & 1 & 0,58 \\
\hline Zeğrek & 1 & 10 & 1 & 0,39 \\
\hline Şıra & 1 & 8 & & \\
\hline
\end{tabular}

Kaynak: Cikia, 1947: 243-248; Cikia, 1941: 239-244.

\section{Tahrir Kayıtlarına Göre Sakuneti Köyü'nde Kullanılan Ă̆ırlık Ölçüleri}

Sakuneti Köyü'nde hububat ve bakliyat türlerinin ölçü birimi olarak kile kulanılmaktadır. Kile 1519 tarihinden itibaren devamlı kullanılmıştır (Taştemir, 1999: 160). Arapça bir kelime olan kilenin İstanbul Kilesi, İbrail ve s. gibi çeşitleri vardır (Pakalın, 1952: 281). İnceleme kaynağımız devrinde başkent İstanbul olduğundan biz ölçü birimi 
olarak Sakuneti için İstanbul kilesini ölçü birimi olarak baz almayı uygun bulmaktayız. Bir İstanbul kilesi 25.656 kg denk gelmekte idi (İnalcık, 2000: 444).

Sakuneti Köyü’nde kullanılan ikinci ağırlık ölçüsü “men” şıra ölçümlerinde kullanılmaktadır. Halil İnalcık "men"'i ağır ve hafih olmak üzere ikiye ayırmaktadır. "Ağır menn" 12 okka, yani 15,388 kg, "hafif menn" ise 6 okka veya da 7,694 kg'dır (İnalcık, 2000: 444).

\section{Hayvancılık ve Arıcılık}

\section{Küçükbaş Hayvan Yetiştirme}

Hayvancılık, Sakuneti Köyü’nün önemli geçim kaynaklarındandır. Zira köyün iklimi hayvan yetiştirilmesinde elverişli idi. Bu yüzden yetiştirilen küçükbaş hayvanlardan olan koyun ve domuz vergiye tabi tutulmuşdı. 1595 tarihli tahrir kayıtlarından vergi kalemi olarak koyunculuk ve domuzculuk kayıt olunmuştur.

1595 tarihli tahrir defterinde Sakuneti Köyü ile ilgili halkın vergi dışı gelirleri kaydedilmemiştir. Örnek olarak hayvanları göstere biliriz. Binek hayvan olan merkep, katır, ziraat işlerinde çok gerekli olan öküz, sığır mal gibiler kayıtlarda gözükmemektedir. Büyükbaş hayvanlardan olan inek, manda halkın et, süt, yağ, peynir ihtiyaçlarını giderdiğinden ve bunlardan gelir amaçlı pazara satlık için götürülmediğinden defter kayıtlarında gözükmemektedir.

XVI. yüzyıl sonlarında Sakuneti köyündeki hayvan yetiştiriciliği hakkında tahrir defterinden bilgi edinmekteyiz. 1595 yılında bu köyde yerleşik yaşam olduğu gibi yayla ve yataklarında, Tupi Tepesi'nin yamaçlarında göçebe halk da yaşamaktaydı. Köy halkı koyunlarını köy yakınlığındaki ormanda ve dağının eteklerinde otlatmaktaydılar. Öküz zirâ̂ hayata çok önemli olmuştur. Arazinin ziraat ürünlerinin ekimi için hazırlanma, hasıl edilen ürünün taşınması köylünün vazgeçilmezidir. İhtiyaçdan dolayı bulundurulan ve ticaret gayesi güdülmeyen atlardan, katırlardan ve eşekllerden, kümes hayvanlarından vergi alınmazd1 (Saydam, 1999: 361).

Osmanlı vergi sistemine göre koyunlardan alınan vergi resm-i ganem, adet-i ağnam olarak bilinmektedir (Çağatay, 1947: 485-486). Sakuneti köyünde bu vergi "adet-i ağnam” şeklinde zikrolunmuştur. Ayrıca 1595 yılında nüfusu gayrimüslim olan Sakuneti'de domuz da yetiştirilmekteydi. Domuzdan alınan vergi "resm-i hınzır" olarak adlandırılmaktadır.

\section{Resm-i âdet-i ağnâm}

Âdet-1 ağnam vergisi, devlet dahilinde Müslüman Gayrimüslim farkı gözetilmeksizin bütün reayâdan eşit bir şekilde iki veya üç koyun başına bir akçe olarak alınırdı (Çağatay, 1947: 485). Sakuneti köyü ile ilgili kayıtlarda bu "resm-i âdet-i ağnâm" şeklinde zikrolunmuş ve köyün önemli gelir kaynaklarındandır. Köy halkı koyunlarını Sakuneti köyünün coğrafi şartları ve otlatma imkânları köyde koyun besiciliğinin yapılmasına imkan sağlamaktadır. Köyün karşı tarafında olan Tupi dağı bu bakımdan büyük önem arz etmektedir. Koyunculuktan hâsıl edilen vergi 300 akçedir. Gürcistân kanunnamesine göre iki koyundan bir akçe "resm-i adet-i ağnam" alınmaktaydı. Defterde "resm-i adet-i ağnam" olarak kayd olunan ve koyun resmi anlamına gelse de keçilerden de alındığı bilinmektedir. İki koyuna bir akçe alındıktan sonra on koyuna bir akçe çubuk akçesi ve her sürüden bir koyun şişlik diye her hangi bir şey alınmamaktadır. Bu verginin alınma zamanı Nisan (Abril) ayı idi (Akgünüz, 1994a: 580). Sakuneti köyünde iki koyuna bir akçe alındığına ve vergisi de 300 akçe olduğuna göre köyde 600 adet koyun olduğunu tespit etmiş oluruz. 
Sakuneti köyünden yatak, yaylak, yonca ve giyah resimleri alındığına göre köy yakınlığında konar-göçer hayat tarzını aşiretleri bulunmaktadır. Onlar besledikleri hayvanlarla hem kendi geçimlerini sağlıyor, hem de Azğur ve Ahıska gibi yakın şehirlerin deri, süt, peynir ihtiyaçlarını karşılamaktaydı. Kayıtlardan da görüldüğü gibi Sakuneti köyünden 120 akçe yatak, 250 akçe yaylak, 350 akçe de yonca ve giyah vergisi tahsil edilmekteydi. $\mathrm{Bu}$ vergiler Sakuneti yaylalarında hayvanlarını otlatan kişilerden alınmaktaydı.

\section{Resm-i hınzır}

Tahririn yapıldığı 1595 tarihinde Sakuneti köyünde yaşayanlar gayrimüslim idiler. Bunlar kendi et ihtiyaçlarını karşılamak için domuz besliyorlardı. Domuzlardan alınan vergi defter kayıtlarında "resm-i hınzır" olarak görülmektedir. Sakuneti köyünden hâsıl edilen yıllık hınzır vergisi 200 akçedir. Gürcistân Kanunnâmesi'nde hınzır vergisi ile ilgili her hangi bir kayıt bulunmamaktadır. Fakat sancak kanunnâmesinde bununla ilgili şu hüküm bulunmaktadır: "Resm-i hanâzır ve bojik, iki canavara bir akçedir, harman sonunda alınur. Ve resm-i bojik dahi kâfirler bojikde (yılbaşında) tepeledikleri hınzırın her birinden ikişer akçe alınur" (Akgündüz, 2006: 188). Bosna Eyâlet kanunnâmelerinden olan Pojega Sancağ1 Kanunnâmesi'nde domuz vergisi ile ilgili şu hüküm bulunmaktadır: "Ve Dafter-i Atîkde iki hınzırdan bir akçe alınmak mukayyed iken 987 senesinde hükmi hümâyûn vârid olub bir hınzırdan bir akçe bid'at alınmak fermân olunmağın emr-i âlî-kadr muktezasınca kayd olundu" (Akgündüz, 1994b: 265). Fakat Simontornya sancağında bir yaşından büyük olan domuzlardan ikişer akçe vergi alınmıştır (Geza Davıd, 1999: 141). Kopan ve Şimontorna Kanunnâme'sinde bu şöyle zikrolunmaktadır: "Ve resm-i hanâzır içün yıl geçmişinden iki akçe alına ve yıl geçmeyenden nesne alınmaya “ (Akgündüz, 1994a: 453). Pojega Sancağ1 Kanunnâmesi'ne göre her domuza bir akçe alındığına göre Sakuneti köyünde beslenilen domuz sayısı 200 adet olduğu görülmektedir.

\section{Yaylak, Yatak, Resm-i Yonca ve Giyah}

Yaylak ve kışlak vergileri, hariçten gelip konaklayan koyun sürülerinden alınmakta olup, yerli halkın koyunlarından alınmamaktadır (Ünal, 1989: 137)._Yaylak-Kışlak Resmi, sürülerini başkasının yerinde veya Miri topraklarda otlatan sürü sahiplerinden veya göçebelerden yılda bir defa olmak üzere alınırdı. Sakuneti köyünden yatak ve yaylak vergisi alındığına göre köy yakınlığında konar-göçer hayat tarzını yaşayan aşiretlerin bulunduğunu söylemek mümkündür. Sakuneti'de konar-göçerlerin Tupi dağ1 eteklerinde olduğunu tahmin etmekteyiz. Onlar besledikleri hayvanlarla hem kendi geçimlerini sağlıyor, hem de Azğur ve Ahıska gibi şehirlerin deri, süt, peynir ihtiyaçlarını karşılıyorlardı. Fakat konar-göçerlerin yetiştirmekte oldukları hayvanlar ziraat için büyük tehlike arzetmekteydi (Güçer, 1964: 14). Yatak vergisine Ağıl vergisi de denir. Yatak vergisinin konusu, kışlatma ve kuzulatmak için sipahinin arazisinde sürüye ağıl yapılması idi. Sakuneti köyünden 250 akçe yaylak, 120 akçe yatak, 350 akçe yonca ve giyah vergisi tahsil edilmekteydi. Bu vergiler Sakuneti yaylalarında hayvanlarını otlatan kişilerden alınmaktaydı.

Köylerde yaşayanlar süt, peynir ve yağ ürünlerini karşılamak için sığır, binek olarak at ve merkep, tarla çalışmalarında kullanmak için öküz beslemekteydiler (Pamuk, 2007: 215). Aynı durumun Sakuneti köyünde de olduğu muhtemeldir. At ve merkep taşımacılık işlerinde, pazara ve bir köyden diğer köye gitmekte önemli yer tutmaktadır. "Resm-i âdet-i ağnâm" adı altında koyun ve keçilerin yetiştirildiği bilinse de reayanın ihtiyaçları için at, öküz, sığır, manda, kaz, tavuk ve s. olması muhakkaktı. Karşılaştırmak 
için nahiyenin bazı köylerinin 1917 yıl tarımsal sayımını burada vermeyi uygun görmekteyiz (Tablo 6).

Tablo 6: 1917 Yıl Tarımsal Sayım-Tiflis Vilâyeti Akhaltsikh (Ahıska) Kazası Sakuneti Köyü.

\begin{tabular}{|l|l|c|}
\hline Hane & 115 & $\%$ \\
\hline Hayvanı Olmayan & 5 hane & 4,85 \\
\hline Çalışan Hayvanı Olmayan & 11 hane & 9,57 \\
\hline Sığırı Olmayan & 37 hane & 32,17 \\
\hline Hayvanı Olanlar & 110 & 95,65 \\
\hline Köydeki Beygir Sayısı & 196 (çalıştırılan), 14 (çalıştırılmayan) & \\
\hline İnek Sayısı & 103 & \\
\hline Dana Sayısı & 99 & \\
\hline Manda & 4 (çalıştırılan) & \\
\hline Dişi Manda & 1 adet çalıştırılan, 6 adet çalıştırılmayan & \\
\hline Manda Yavrusu & 1 adet & \\
\hline Merkep Sayısı & 71 adet çalıştırılan, 2 adet çalıştırılmayan & \\
\hline Katır Sayısı & 8 & \\
\hline Köydeki Çalıştırılan Hayvan Sayısı & 280 & \\
\hline Hane başına & 2,43 adet & \\
\hline Koyun & 584 adet & \\
\hline Keçi & 81 & \\
\hline Köydeki Koyun ve Keçi Toplamı & 665 & \\
\hline Köydeki Toplam Hayvan Sayısı & 1.170 & \\
\hline Hane Başına Düşen Hayvan & 10.17 & \\
\hline
\end{tabular}

Kaynak: Selskokhozyaystvenniy perepis 1917, 1917: 84.

Tablodan da görüldüğü gibi köyde reaya beygir, inek, manda, eşek, katır, koyun ve keçi bulundurmaktaydı. İncelediğimiz dönem öncesi ve sonrası hayvancılık köy ekonomisine bir çok alanda katkılar sağlamaktaydı. Bu katkıyı şu şekilde özetliye biliriz:

Tarım alanında: Toprakları ekmekte öküz ve mandadan istifade olunurdu.

Gıda alanında: Hayvanların etinden, yağından, peynirinden, sütünden yaralanıyor.

Ulaşım alanında: At, katır, eşek gibi hayvanlardan taşıma ve ulaştırma işlerinde kullanıliyordu.

Sanayi alanında: Hayvanların yünü ve derisi giyim, ayakkabı ve dokumacılıkta hammadde idi. 
Maliye alanında: Hayvancılık ve onlarla ilgili ürünlerden alınan vergiler devletin en önemli gelir kaynağını oluşturmaktaydı.

\section{Arıcılık}

Samtskhe-Cavakheti ormanları ve ekoloi temizlik ortamı bölgede arıcılık için imkân sağlamaktadır (URL-21). Her ne kadar arıcılığın ekonomik etkisi olmasa da bu imkân Sakuneti köyünde de görülmektedir. Tahrir defterlerinde baldan alınan vergi, resm-i asel, resm-i zenburiye, öşr-i kovan, resm-i kevvâre ve öşr-i petek şeklinde kullanılmaktadır. Sakuneti köyünde bu vergi "resm-i kevvâre" olarak kaydedilmiştir. Arıcılar arılarını kendi tımar arazileri dışındabesledikleri zaman verginin yarısını kayıtlı olduğu sipayiye, diğer yarısını da arıların otlandığ 1 tımar sipahisi alırdı. Sakuneti köyünde mevcut coğrafi şartlar re'ayanın kendi arazisinde arılarını beslediği şüphesizdir.

Tahrir defteri kayıtlarında "resm-i kevvâre" adı altında bir vergi alınmaktadır. Kevvare, arıların bal yaptıkları yuvaya denmektedir (Arslan, 2005: 58). Sakuneti köyünün bağlı bulunduğu Azğur nahiyesinde bal üretimi geniş ölçüde yapıldığı anlaşılmaktadır. Arı besleyen ve bal üretimi nahiyenin birkaç köyü hariç tümünde yapıldı̆̆ tahrir kayıtlarından gözükmektedir. İncelenen tarihte, yani 1595 yılında Sakuneti köyünde bal üretimi yapılıyordu. "Gürcistân Vilâyeti Kanunnâmesi'nin 25. Maddesi gereğince " resm-i kevvâre öşr-i 'aselden bedel her kovandan ikişer akçe alınur" olup bal öşrünün kovan başına iki akçe olarak tahsil edildiği görülmektedir (Iasha Bekadze, 2015: 127). Arı1cılıktan 200 akçe bal vergisi alındığına göre köyde 100 adet kovan bulunmaktadır.

\section{Balıkçılık}

Çıldır, nâm-ı diğer Ahıska Eyâleti'nde balıkçılık hem tatlı hem de tuzlu sularda yapılmaktaydı. 1595 tarihli tahrir defterinde balıkçılıkla ilgili verginin hem tatlı suyu olan Kür Nehri'nin Niala-Toba köyleri, Cak suyu ile Badele suyu arasındaki kısımlardan, Marih Nehri'nden, hem de Tabitskur, Sağamo, İskunduriya, Hançeri, Büyük Horeniya, Çıldır göllerinden balık öşrünün alındığı defter kayıtlarından görülmektedir (Iasha Bekadze, 2015: 127). Fakat bu vergi Kür Nehri'nin sağ tarafında yerleşen Sakuneti köyü vergileri içerisinde gözükmemektedir. Halkın burada kendi ihtiyaçları için balık tuttukları muhtemeldir. Pazarda satılık için balık tutulmadığından vergiye tabi olmamıştır.

\section{Reayadan Alınan Vergiler \\ İspenç resmi}

Osmanlı İmparatorluğu'nda gayrimüslimler 16. yüzyılın ortalarına kadar çift resmini ödemekteydiler. XVI. yüzyılın ikinci yarısında ise bu statü değiştirilerek ispenç vergisini ödemekteydiler (Acun, 2006: 75). İspenç resminin menşei Osmanlı öncesine uzanmaktadır (Ünal, 1999: 120). Osmanlı Devleti’nde ergenlik çağına gelmiiş ve akıl sağlığı yerinde olanlar bu vergiyi öderlerdi. Hasta, sakat, işsiz ve din adamı olmayan 14-75 yaş arasındaki faal bütün gayrimüslim erkekler öderlerdi (Yörük, 2007: 626). Sadaka ile geçinen rahipler, çalışamayacak kadar hasta olan fakirler, 14-75 yaşlarından küçük ve büyük olanlar ve kadınlar bu vergiden muafidiler.

Macaristan'da bu vergi "kapu resmi” adı altında yılda iki kez 25 akçelik taksitlerle alınmaktaydı (Taşkın, 2007: 638). Bu veginin miktarı Mardin ve Harput'ta da 25 akçe olmuştur. Fakat Kerkük'te Uzun Hasan kanunlarına eklenen maddede bu vergi Hristian ve İbraniler için yirmişer akçe belirlenmişti. İspenç vergisi XVII. yüzyılda 100 akçeye çıkarılmıştı. 1716'da Mora Venediklerden geri alındığg zaman ispenç Hrstiyanlar için 25, 
İbraniler için 125 akçe, 1727'de Gence'de ise ispenç 120 akçe olmuş, Karaman, Rum ve Arap eyaletlerinde ispenç alınmamıştır (İnalcık, 1959: 60-61).

1595 y1lında Sakuneti köyünde yaşayanlar gayrimüslim olduğundan onlardan ispenç vergisi alınmaktaydı. Gürcistân Kanunnâmesi'nin ilk maddesinde bu verginin miktarı şöyle ifade edilmektedir: “... Vilâyet-i Gürcistân sengistân olub toprakları az olmakla defter-i 'atîk mucibince her nefer başına duta geldikleri yerleriyle yirmibeşer akçe ispençe kayd olundu” (Akgündüz, 1994a: 578). Sakuneti köyünde vergi yükümlüğü olan 14 kişiden 25'er akçe olmak üzere toplam 350 akçe ispenç hâsıl edilmekteydi.

\section{Resm-i murahhasiye be her hâne-i fi 2}

1595 tarihli defterde "resm-i murahhasiye" ve "resm-i murahhasiye be her hâne-i fi 2" şeklinde kaydolunan bu vergi kilise vakıfları ve piskoposlara ait arazilerde, piskoposun yararına ödenmekteydi (Bekadze, 2016: 170). Gürcistân Kanunnâmesi'nde bu, “ve vilâyet-i Gürcistân'da murahhasiye deyü nefer başına ikişer akçe alınurmış; re‘âyâya tahfif içün defter-i cedîd-i hâkânîde kayd olundığı üzere beher hâne ikişer akçe alınub ziyâde alınmaya" şeklinde zikrolunmaktadır (Akgündüz, 1994a: 581). Sakuneti köyünde vergi hükümlülü 14 hane reisi olduğundan bu köyde elde edilen murahhasiye vergisi 28 akçedir (TTD, 1003 (1595): 52; Cikia, 1947: 92)..

Köyde olan üç aile reisi; Giorgi keşiş ve onun kardeşi Mehrebil dini görevli, Mehmed bin Abdullah da Müslüman olduğundan murahhasiye vergisi ödememekteydi.

\section{Bâd-ı Havâ Resimleri}

Bâd-i-Hava vergileri “şer'î hükümler ve divânî zaruret ve ihtiyaçlar olmadan ülü'lemrin arzu ve iradesiyle konulan vergilerdir" (Saydam, 1999: 369). Sakuneti köyünde bâdî-hava vergileri şunlardır: Resm-i arûs, resm-i tapu, resm-i deştbâni. Bunlar, Sakuneti köyünde cereyan eden olaylarla ilgili vergi çeşitleridir.

\section{Resm-i arûs}

Resm-i arûs vergisi evlenen kadınlardan alınmakta olup eyalet kanunnamelerinde tayin edildiği miktarda kocası tarafindan ödenmekteydi. Ayrıca bu miktar gelinin kız, dul, Müslüman ve Hıristiyan olmasına göre değişmekte olup kızlar için 60, dullar için 30 akçe idi. Hırıstiyan kızları için 40, dulları için ise 15 akçe olarak belirlenmişti (Sertoğlu, 1992: 910). Kızlar ve kadınlar evlendikleri zaman yapılması gereken ödemelerle ilgili hükümler Gürcistân Kanunnâmesi'nin 28. Maddesinde şöyle zikrolunmuştur: "Ve resm-i 'arusiyye mîrlivâ ve zu'amâ ve saîr serbest olan tîmarlardan bâkire kızlardan altmışar akçe ve seyyibe 'avretlerden otuzar akçe alınur. Ve sâir erbâb-1 tîmârın 'arusiyye resmi nısfi kayd olunan yerlerden sipahiler ve nısf-1 âhara mîrlivâya kayd olunan yerleri ancak zâbitler alalar. Ve bâkire kızın 'arûsiyesi her ne yerdengöçürürse ve atası kimin ra'iyyeti ise ana verir. Ve seyyibe 'avret her kimin toprağında vâki' olursa resm-i arûsiyesin sâhib-i tîmâra verir" (Akgündüz, 1994a: 580). Kopan ve Şimontorna Kanunnâmesi'nde ise resm-i arûs Müslümanların bâkiresinden altmış akçe ve bîvesinden otuz akçe ve zimmîlerin bâkiresinden otuz akçe ve bîvesinden on beş akçe" alınması yasalanmıştı (Akgündüz, 1994a: 454). 1595 tarihli tahrir defterinde Sakuneti ile ilgili kayitlarda bâd-i havâ ve resm-i arûs adı altında 132 akçe vergi alınmaktaydı.

\section{Resm-i Tapû}

Tapu Hukuku: "Dışarıdan gelen halkın tasarrufunda bulunan tapulu yerlerini elinden alıp, başka bir yere vermek yasaklanmıştır”. Toprağı işleme hakkı verilen köylüden toprak sahibi tarafından alınan vergiye tapu denmektedir ve miktarı, Diriliğin bulunduğu bölgeye 
göre değişmektedir (Sertoğlu, 1992: 11). Çoğunlukla arazinin bir yıllık ürününün bedeli kadardır. Bu ödemeyi yapanlar ömrünün sonuna kadar arazi üzerindeki tasarruf hakkını sürdürür ve arazinin tasarruf hakkını çocuklarına miras bırakabilirdi. Gürcistân Kanunnâmesi'nde Tapu ile ilgili hükümler 5, 6, 10, 11, 12, 13. maddelerde açıklı̆̆a kavuşturulmuştur. Tapu vergisinin miktarı değişik şartlara bağlıydı. Kanunnâmenin 10. Maddesi gereğince ala yerden iki dönüme bir akçe ve edna yerden üç dönüme bir akçe alınmaktadır (Iasha Bekadze, 2015: 119).

\section{Resm-i Deştbâni}

Bu resim, 1595 tarihlidefterde "cerâim-i hayvanât" adı altında zikredilmekte olup herhangi bir şahsın hayvanının başkasının ekinine girdiğinde ödediği cerime, yani para cezasıdır. Zarar gören ekin sahibinin zararları ödenerek hayvan sahibine "beş değnek" vurulması ve değnek başına beş akçe tımar sahibine ödenmesi emredilmiştir. Ayrıca bu konuda "resm-i deştbâni" diye her haneden maktu bir vergi alınmaması kaydedilmiştir. Gürcistân Kanunnâmesi'nde bu husus şöyle zikrolunmaktadır: "Cerâyim- hayvânât dahi re'âyanın atı ve sığırı ve bil-cümle çâr-pâ cinsi birbirilerinin ekinlerine ziyân etse, zararları tazmin etdirildikten sonra davar sâhibine beş değnek urulub davar başına beş akçe sâhib-i tîmâr cerîmein ala. Koruyub dutulan davarlardan zikr olunduğı üzere alınub resm-i deştbânî deyü her hânden maktû‘ edüb nesne alınmaya(Akgündüz, 1994a: 581).

Azğur Nahiyesi’nin tam tahrir dökümü verilmiş 38 köyünün Okire ve Beyt köyleri hariç tümünden tapu ve deştbani vergisi alınmaktadır. Bu vergi bazen "resm-i tapu" ve "resm-i deştbânî" olarak ayrı ayrılıkda, bazen de "resm-i tapu ve deştbânî" şeklinde vergilendirilmiştir. Nahiyenin Moksev, Tsinis, Zikilia ve Çohta köylerinde ayrı ayrılıkta "resm-i tapu" ve "resm-i deştbânî” (TTD, 1003 / 1595: 53-56; Cikia, 1947: 94-95, 98, 100), diğer köylerde ise "resm-i tapu ve deştbânî" şeklinde vergilendirilmiştir. Sakunet köyü de "resm-i tapu ve deştbânî" şeklinde vergilendirilen köyler arasında yer almaktadır. Bu köyden yıllık elde edilen hasılat 200 akçedir (TTD, 1003 / 1595: 52; Cikia, 1947: 91-92).

\section{Sakuneti Köyü'nde Küçük Sanayi İşletmeleri}

Değirmenler, hububatın öğütülmesinde kullanılmakta olup kır yerleşim alanlarının en küçük işletmeleridir. Değirmencilik, tarımsal sanayinin en önemli ve en eski kolu olup su ve yel değirmenlerinden meydana gelmiştir. (Bekadze, 2016: 173). Tahrir defterinde Azğur Nahiyesi'ndeki değirmenler "âsiyab", yani su değirmeni olarak kayd edilmiştir. Âsiyâb pehlevi kökenli kelime olup "âsiyâ" değirmen ve "ab" su anlamina gelmektedir (Şemseddin Sami, 2011: 36). Tahrir defterinde her değirmen "bab", yani çalışan değirmen taşı olarak belirtilmiş ve vergi de "bab" üzerinden alınmıştır. Kanunâme'de değirmen vergisi "resm-i âsiyâb dahi defterde kayd olundığı üzere alınub tamam yıl yürüyenden altmış akçe alına ve altı ay yürüyenden otuz akçe resm-i âsiyâb alına; ziyâde alınmaya. Ve Vilâyet tahririnden sonra eski ocakdan âsiyâb binâ olunsa civârında olan âsiyâblardan ne alınursa sâhib-i timâr anlara göre resm alub ziyâde alınmaya. Ammâ eski ocak olmayub tahrirden sonra binâ olunsa, mevkûfcınındur; sâhib-i arz dahl eylemeye" (Akgündüz, 1994a: 580) şeklinde zikrolunmuştur. Sakuneti köyünde yıl boyu çalışan iki değirmen olduğu kayıtlardan bilinmektedir. Bu değirmenlerin suyun yeterli olmasından dolayı yıl boyu çalışması defterde "Âsiyâb 2 bâb sene-i kamila" şeklinde zikredilmiştir. Bu değirmenlerin Kür Nehri suyundan yararlandığg kesinlik kazanmaktadır. Zira Kür Nehri’nin suyu yılın tüm aylarında kesilmemektedir. Köyde değirmen vergisi olarak iki bâbdan toplam 120 akçe alınmaktadır.

\section{Sakuneti Köyü’nden Alınan Bazı Vergilerin Tahsil Zamanı}


Osmanlı kanunlarında bazı vergilerin tahsil zamanı belirtilmiştir. Sakuneti köyü ile ilgili olan birkaç vergi türü ve alınma zamanı gösterilmiştir.

İspenç resmi, bazı yerlerde bir defa Mart ayının evvelinde, bazı yerlerde "yarısı ruz-u hızırda, yarısı ruz-u kasımda" (Çağatay, 1947: 508);

Adet-i ağnâm resmi, Abril (Nisan) ayında (Akgündüz, 1994a: 580);

Bağ resmi, genellikle bağ bozumundadır, yani Eylül sonlarında (Çağatay, 1947: 489);

Bahçe ve bostan, her ürünün yetiştiği ve toplandığı mevsimde (Çağatay, 1947: 490);

Yaylak resmi, İlkbaharda, Nevruz'da (Çağatay, 1947: 510);

Resm-i Küvvare, Erzurum'da baharda, Temmuz'un ondokuzuncu günü, Estergen, Budin, Hatvan, Novigrad'da harman vaktinde, Mora'da ise güz aylarında (Çağatay, 1947: 509);

Değirmen resmi, bazı eyâletlerde harman vaktinde, bazılarında ise baharda, yani Temmuz'un dokuzuncu gününde (Çağatay, 1947: 504) alınmaktaydı.

\section{Sakuneti Köyü'nde Mülkiyet Düzeni}

XVI. yüzyılda bazı Balkan ülkelerinde olduğu gibi Çıldır Nâm-ı diğer Ahıska Eyâleti'nde de eski mülklerin bir kısmı Osmanlılar tarafindan Hıristiyanların elinde bırakılmıştır. Bunun bir örneği Sakuneti köyünde görülmektedir. Şöyleki Giorgi keşiş ve kardeşi Mehrebil'in Samtskhe-Saatabago zamanındaki bağı Osmanlı zamanında da onların mülkiyetinde kalmıştır. Ve bu bağın bir hissesi ise Müslüman Mehmed Abdullah oğlu tarafından kiralanmış bulunmaktadır (TTD, 1003 / 1595: 52). Keşişlerin arazi sahipliğine 1574 tarihli ilk Gürcistân tahrir defterinde de rastlanmaktadır. Söz konusu araziler onlara belirli bir şartlara göre verilmiş idi (Shengelia, 2005: 1502).

\section{Mukataa}

Arazinin belirli bir bedel karşılığında kiraya verilmesine mukataa denir (Şahin, 2013: 1022). Defter kayıtlarından belli olduğuna göre Sakuneti köyünde bağını kiraye verenlerden Giorgi keşişin ve onun kardeşi Mehrebilin adı geçmektedir. Bağı kiraye eden ise Mehmed Abdullah oğlu idi. Şer'i mahkeme kararı gereğince Mehmed Abdullah oğlu kiraladığı bağ için yıllık maktu olarak ödediği tutar 20 akçe idi (TTD, 1003 (1595): 52). Sakuneti köyünde Giorgi isminde keşişin olması köyde ortadoks din görevlisinin dini görevleri icra ettiğini göstermektedir.

\section{Sakuneti Köyü'nde Vergi Muafiyetleri}

Osmanlı İmparatorluğu'nda hizmetliler vergiden muaf tutulmuşlardı. Bunlar konargöçer yörük ve tatarlar, çiftçilerden yaya ve müsellemler doğancı ve yuvacılardı. Ayrıca ümera ve ilmiye sınfından da bazı görevliler vegiden muaf idiler (Arslan, 2005: 127). 1595 tarihli tahrir defteri kayıtlarından görüldüğü gibi Sakuneti köyünde yaylak ve yatak vergisi elde edilen ve defterde ismi geçmeyen konar göçerlerden herhangi bir vergi alınmamaktadır. Ayrıca el-muaf kategorisi dini görevliler, onların çocukları ve zaviye görevlilerini de kapsamaktadır (Acun, 2006: 80). Defterde ismi geçen Giorgi keşiş ve kardeşi Mehrebil "el-muaf" kategorisinden olduklarından vergiden muaf tutulmuşlardır. Onlardan ispenç ve murahhasiye vergisi alınmamaktadır. Ayrıca keşiş Giorgi ve onun kardeşi Mehrebil'in bir hisse bağını kiralaya Mehmed bin Abdullah'ın da vergiden muaf tutulduğu görülmektedir. Onun maktu olarak ödediği yıllık 20 akçe ise kiraladığı bağ için idi. 
Devletin, 17 hanelik 14 mükellefli Sakuneti köyünden 1595 yılında aldığı verginin toplamı 12. 400 akçedir. Bu verginin en yüksek miktarda olanlar 3600 akçesiyle buğdaya, 4000 akçesiyle arpaya, 1200 akçesiyle şıraya ait olmaktadır. En düşük vergi miktarı ise 60 akçesiyle baklaya aittir. Köyün mükellef başına vergi miktarı 885,71 akçe civarındadır. Köyün ekonomik yapısının zayıf olduğu görülmektedir. Ziraî üretim tüketim ihtiyaçlarını tam karşılamadığını söylemek mümkündür.

\section{Ahıska-Agara-Sakuneti Yollarının İyileştirilmesi}

Ahıska stratejik öneme sahip olmakla birlikte, aynı zamanda ticari bir yolun üzerinde bulunmaktaydı. Bunun yanı sıra Anadolu ile Kafkasya yolunun köprüsü ve geçiş noktasıydı. Bu yüzden klasik dönemde düzenlenen seferlerde Osmanlı orduları Anadolu ile Kafkasya toprakları üzerindeki yollardan yararlanmaktaydı. Bunun içindir ki, ana ve ona bağlı tali yolların iyileştirilmesi ve tamirine büyük önem verilmekteydi. Osmanlı Devleti için Anadolu'yu Kafkasya'ya bağlayan Ahıska- Azğur anayolunun düzgün ve bakımlı olması, çok önemliydi. Genelde Osmanlı Devleti zamanında belli bir görev karşılığında halkın vergiden muaf tutulduğu bilinmektedir. Örnek vermek gerekirse Fatih Sultan Mehmet, Sinop Kalesi'ninkorunması için Sinop halkını tüm avarız vergilerinden muaf tutmuş ve bu durum 16. yüzyıl boyunca diğer padişahlar tarafından da onaylanmıştır (Faroqhi, 1993: 133). Aynı şekilde Ahıska Sancağı Güney Nahiyesi reayasız köylerinden ve yıllık 10.200 akçe vergisi olan Tsinis Köyü tekâlif vergisinden muaf tutulmuş ve o köye, $22 \mathrm{~km}$ uzunlukta olan Ahıska-Azğur yolunun iyileştirilmesi ve tamiri işleri verilmişti (Shota Bekadze, 2014: 130).

\section{Sonuç}

Hicri 1003 (1595) tarihli Tapu Tahrir Defteri alınan vergi oranlarından hareketle Sakuneti köyünün XVI. yüzyıl sonlarında tarım, hayvancılık ve sanayiden oluşan ekonomik yapısını yansıtan en önemli arşiv belgesidir. Zira bu belge XVI. yüzyıl sonundaki köyün ekonomik durumunu geniş ölçüde yüze çıkaracak düzeydedir. O devrin genelinde olduğu gibi Sakuneti köyünde de ekonomik yapının temelini tarım ve hayvancılıktan alınan vergiler teşkil etmektedir. Toplam gelir vergisinin \% 93 ünü tarım ve hayvancılıktan alınan vergilerden ibarettir.

Sakuneti köyü, XVI. yüzyıl sonlarında Azğur Nahiyesi'ne bağlı bir köy durumundadır. Sakuneti köyü hakkında ilk resmi belgenin 1595 tarihine ait olsa da köyün daha önceler Samtkhe-Saatabago Devri'nde mevcut olduğunu söylemek mümkündür. Sakuneti köyünde 1595 tarihli tahrir defteri kayıtlarına göre 17 hane olan köyün, vergi mükellef sayıs1 14'dür. Bu yıllarda hane sayısı ve erkek nüfusu bilgilerinden yararlanarak, tahmini nüfusun 136 kiş olduğu görülmektedir. Daha sonralar, 1870 de 320 kişi, 1886'da 499 kişi, 1917 de 759 kişi, 1944 de ise 855 kişi olarak görülmektedir. 14 Kasım 1944'de boşalan köye getirilen nüfus sayısı ise elde ettiğimiz bilgilere göre şöyle değişmiştir: 2002'de 593 kişi, 2014'de 472 kişiye kadar azalmıştır.

Bu köyün sosyal ve ekonomik yapısını incelediğimizde geçim kaynaklarının tarım ve hayvancılıktan ibaret olduğu görülmektedir. Tarımsal faaliyetlerde yetiştirilen en önemli ürünler buğday ve arpadır. Az miktarda da olsa çavdar ve erzen de yetiştirilmektedir. Köyde üzüm de yetiştirilmektedir.

Sanayi öncesi toplumların geçim kaynağını oluşturan hayvancılık da köy ekonomisine önemli derecede katkılar sağlamıştır. Hayvancılıktan alınan vergiler bunu kanıtlamaktadır. Köyden hâsıl olunan vergi miktarı 12.400 akçedir. 
1595 tarihli tapu tahrir defteri, köyün sosyal ve ekonomik yapısını ortaya koymaktadır. Köyün geliri, üretimi ve vergi kalemleri hakkında bir görüntü oluşmaktadır. Bu görüntü, tarımsal ve hayvancılık faaliyet kaynaklı bir ekonomik yapıya sahip olduğunu göstermektedir. Hatta tarımsal ve hayvansal üretim durumunun köyün ihtiyaçlarını tam karşılamaya yeterli olmadığı sonucu ortaya çıkmaktadır.

Sakuneti köyünde, değirmen haricinde başka sanayi işletmesi bulunmamaktadır.

XVI. yüzyıl sonlarında Samtskhe-Javakheti köylerinin sosyal ve ekonomik yapısı tahrir defterleri ışığında pek incelenmemiştir. Sakuneti köyü örneğindeki bu çalışmamız önemli adımlardan olup Samtskhe-Javakheti'nin diğer köylerinin XVI. yüzyıl sonlarındaki sosyal ve ekonomik yapısı hakkında fikir sağlamaktadır.

\section{KAYNAKÇA}

\section{Arşiv Vesikaları}

Tapu ve Kadastro Genel Müdürlüğü Tapu Arşivi'nde: Yeni Sıra No: 10, Fon Kodu: TKG. KK.TTd. 10 ve Defter Eski No: 58/130

\section{Basılı Eserler}

ACUN, Fatma (2006). Karahisar-ı Şarki ve Köylühisar Kazaları Örneğinde Osmanlı Taşra İdaresi (1485-1569). Ankara. Türk Tarih Kurumu.

Ahıska və Ahıskalılar, Bizim Asır. Müsteqil ictimai-siyasi qezeti, sayı 28 (448).

AKDAĞ, Mustafa (1995). Türkiye'nin İktisadî ve İctimaî Tarihi. Cilt I. 1243-1453. İstanbul. Cem Yayınevi.

AKGÜNDÜZ, Ahmed (1994a). Osmanlı Kanunnâmeleri ve Hukukî Tahliller. 7/II. Kitap. II. Selim Devri Kanunnâmeleri. İstanbul. Osmanlı Araştırmaları Vakfi.

AKGÜNDÜZ, Ahmed (1994b). Osmanlı Kanunnâmeleri ve Hukukî Tahlilleri. 8/I. Kitap. III. Murad Devri Kanunnâmeleri. 8/ II. Kitap. III. Mehmed Devri Kanunnâmeleri. İstanbul. Osmanlı Araştırmaları Vakfı.

AKGÜNDÜZ, Ahmed (2006). Osmanlı Kanunnâmeleri ve Hukukî Tahlilleri. 1. Kitap. Osmanlı Hukukuna Giriş ve Fatih Devri Kanunnâmeleri. 2. Baskı. İstanbul. Osmanlı Araştırmaları Vakfı.

APAKIDZE, Andria (1963). Kalakebi da Sakalako Tskhovreba Dzvel Sakartveloşi. (Eski Gürcistan'da Şehirler ve Şehir Hayatı). Tbilisi. SSR Metsnierebata Akademia.

ARSLAN, Lütfi (2005). H.963/M.1556 Tarihli Mufassal Tahrir Defterine Göre Bozok Sancağı'nın Ekonomik ve Demoğrafik Yapısı, (Ankara Üniversitesi Sosyal Bilimler Enstitüsü Yeniçağ Tarihi Anabilim Dalı, Yayımlanmamış Yüksek Lisans Tezi), Ankara.

BALASANIYANI, Mariam (2016). Samtskhe-Cavakhetis Toponomia "Somkhetisa da Misi Mimdebare Teritoriis Toponimebis" khuttomeulis mikhedvit. Sadisertasio naşromi şesrebulia pilologiis doktoris akademiuri kharikhis mosapoveblad. Tbilisi.

BARKAN, Ömer Lütfi (1941). “Türkiye'de İmparatorluk Devirlerinin Büyük Nüfus ve Arazi Tahrirleri ve Hakana Mahsus İstatistik Defterleri," İstanbul Üniversitesi İktisat Fakültesi Mecmuası, II / I. 
BARKAN, Ömer Lûtfi (2001). XV ve XVI ıncı Asırlarda Osmanlı İmparatorluğunda Ziraî Ekonominin Hukukî ve Malî Esasları. Birinci Cilt. Kanunlar (Tıpkıbasım). Hazırlayan Hüseyin Özdeğer. İstanbul. İstanbul Üniversitesi İktisat Fakültesi Yayını.

BEKADZE, Iasha(2015), “Gürcistân Vilâyeti Kanunnâmeleri'nin Değerlendirilmesi”, Karadeniz-Black-Sea-Черное море, Uluslararası Hakemli Sosyal Bilimler Dergisi, ss, 115-134, Ardahan Üniversitesi İnsan, Bilimler ve Edebiyat Fakültesi Türk Dili ve Edebiyatı Bölümü, Ardahan / Türkiye

BEKADZE, Iasha: (2016), “XVI. Yüzyıl Sonlarında Hertvisi Nahiyesi”, KaradenizBlack-Sea-Черное море, Uluslararası Hakemli Sosyal Bilimler Dergisi, ss, 153-179, Ardahan Üniversitesi İnsan, Bilimler ve Edebiyat Fakültesi Türk Dili ve Edebiyatı Bölümü, Ardahan / Türkiye

BEKADZE, Iasha, YİĞíT, Bekir Tarık(2016). "XVI. Yüzyıl Sonlarında Çıldır Nâm-1 Diğer Ahıska Eyâleti Vakıflarına Genel Bir Bakış”, Karadeniz-Black-Sea-Чepнoe мope, Ụ̈ç Ayda Bir Yayınlanan Uluslararası Hakemli Sosyal Bilimler Dergisi. Sonbahar 2016, Ardahan Üniversitesi İnsani Bilimler ve Edebiyat Dergisi. Y11 8, Sayı 31, ss. 247-264. Ardahan Üniversitesi İnsani Bilimler ve Edebiyat Fakültesi, Türk Dili ve Edebiyatı Bölümü, Ardahan / Türkiye.

BEKADZE, Shota (2012). "1595 Tarihli“ “ Defter-i Mufassal Vilayet-i Gürcistan” Tahrir Defteri’ne Göre Azğur Nahiyesi" , I. Türkiye Lisansüstü Çalışmaları Kongresi, 225-244. 29 Haziran-01 Temmuz 2012, Konya.

BEKADZE, Shota (2014a). "Osmanlı Arşivleri-Bir Kültür İmparatorluğu” (Yayınlanmamış), ss. 1-39. XVII. Türk Tarih Kongresi / XVIIth Turkish Congress of History, 15-19 Eylül 2014. Ankara

BEKADZE, Shota (2014b). “XVI. Yüzyılda Çıldır Eyaleti Ahıska Sancağı'nın Politik ve Sosyo-Ekonomik Durumu”, Ankara Üniversitesi Sosyal Bilimler Enstitüsü Siyaset Bilimi ve Kamu Yönetimi Anabilim Dalı, Yayınlanmamış Yüksek Lisans Tezi, Ankara.

BERIDZE, Merab (2006). Kartvelta Mamuslibeba da Gvaris Şetsvla Meskhetşi (Convertion of Georgians to Moslemism and Changing of Family Names in Meskheti). Redaktori: P. Tskhadaya. Tbilisi.

BOSTAN, M. Hanefi (2002). XV-XVI. Asırlarda Trabzon Sancağında Sosyal ve İktisadî Hayat. Ankara. Türk Tarih Kurumu Basımevi.

CAPARIDZE, Mitropolit Ananiyia (2008). Meskheti Musulmanizasiya Gruzin. Tbilisi. İzdatelstvo "Universal".

CİKİA, Sergi (1941). Gurcistanis vilayetis didi davtari (Defter-i Mufassal Vilayet-i Gürcistan), Kitap II, Tbilisi, Sakartvelos SSR Metsnierebata Akademiis Gamomsemloba.

CİKİA, Sergi, (1947). Defter-i Mufassal Vilâyet-i Gürcistân. Türkçe Metni Tercüme, Tetkik ve Tahşiye Eden S. Cikia. Birinci Kitap. Metin. Tbilisi. Gürcistân S. S. Cumhuriyeti Ulum Akademisi Neşriyat Evi.

ÇAÇAN, Berna (2015). “Osmanlı Devleti’nde Vergi Sistemi Ve Bir Çeşit Vergi Toplama Usulü Sistemi: Temettuat Defterleri”, ss. 9-18. Electronic Journal of Vocational Colleges-May/Mayıs 2015 
ÇAĞATAY,Neş'et“'Osmanlı İmparatorluğu'nda Reâyâdan Alınan Vergi ve Resimler”, A. Ü. Dil Tarih Coğrafya Fakültesi Dergisi, V/5, Ankara (1947), s. 483-511.

DALGALI, Fatih (2008). 45 Numaralı Tapu Tahrir Defteri’ne Göre Simav Nahiyesi (Yayınlanmamış Yüksek Lisans Tezi). Dumlupınar Üniversitesi Sosyal Bilimler Enstitüsü. Kütahya.

DATUKIŞVİLI, Malkhaz (2009). İvane Cavakhişvilis Sakhelobis Tbilisis Sakhelmtsipo Universiteti Humanitarul Metsnierebata Pakulteti, Arkelogia, Arkeologiis doktoris Akademiuri Khariskhis Mosapoveblad Tsarmodgenili dissertasia. Tbilisi, 2009. http://old.press.tsu.ge/GEO/internet/disertaciebi/DISERTACIA\%20-\%20M.

DATUKISHVILI. pdf

DZHAPARIDZE A. (2008). Mesheti. Tbilisi. İzdatelstvo“Universal”.

FAROQHI, Suraıya (1993). Osmanlılarda Kentler ve Kentliler. Çeviren: Neyyir Kalaycıoğlu. İstanbul. Tarih VakfiYurt Yayınları

GAPRINDASHVILI, Giorgi (2016). Sakartvelos Samkhret mtianetis geodinamikuri prosesebi da mosalodneli geoekologiuri gartulebebi. Sadoktoro disertasia. İvane Cavakhişvilis Sakhelobis Tbilisis Sakhelmtsipo Universiteti. Tbilisi. 2016. Geodynamic processes and expected geo-ecological complications in Southern Highlands of Georgia, Dissertation, Ivane Javakhishvili Tbilisi State University, Faculty of Exact and Natural Sciences Department of Geography, Tbilisi.

GAPRINDASHVİII, George, GERKEULİ, Tamaz, TSERETELİ Emil, GAPRINDASHVİLI, Merab (2016). Geological Hazards in Samtskhe-Javakheti Region (Georgia). International Journal of Geosciences, 2016, 7, 311-324, Published Online March 2016 in SciRes. http://file.scirp.org/pdf/IJG_2016032214415040.pdf. Erişim Tarihi: 30.03.2017.

GEZA Dâvıd (1999). Osmanlı Macaristan'ında Toplum, Ekonomi ve Yönetim. 16. Yüzyılda Simontornya Sancağı. Çev. Hilmi Ortaç. İstanbul. Tarih Vakfı Yurt Yayınları 81 .

GÖYÜNÇ, Nejat (1979), "Hane Deyimi Hakkında”, İstanbul Üniversitesi Edebiyat Fakültesi Tarih Dergisi, 32, ss.331-348.

GÖYÜNÇ,Nejat (1997). "Hane”, TDVİA 15, Ankara, ss. 552-553.

GÜÇER, Lütfi (1964). XVI-XVII. Asırlarda Osmanlı İmparatorluğu'nda Hububat Meselesi ve Hububattan Alınan Vergiler'.'Istanbul. Sermet Matbaası Şemsi Arkadaş.

GÜL, Abdülkadir(2009). "XVI. Yüzyılda Antakya Kazası'nın Demografik Yapısı / The Demographic Structure of Antioch Town in XVI. Century", TURKISH STUDIES International Periodical for the Languages, Literature and History of Turkish or Turkic-, (Prof. Dr. Hamza Zülfikar Armağanı), Volume 4/3 Spring 2009, www.turkishstudies.net, p. 1024-1066

GÜLENSOY, Tuncer (1984). “Dîvânü Lügati’t-Türk ve Kutadgu Bilig'deki Moğolca Kelimeler Üzerine”. Türk Kültürü Araştırmaları, Necati Akder Armağanı, XXII / 1-2, 90-103, Ankara.

GÜMÜŞ, Nebi (2000). XVI. Asır Osmanlı-Gürcistan İlişkileri (Doktora Tezi). Marmara Üniversitesi Sosyal Bilimler Ensitüsü. İslâm Tarihi ve Sanatları Ana Bilim Dalı. İstanbul. 
GÜNEŞ, Ahmed (1994). "XVI. Yüzyıl Başlarından XVII. Yüzyıl Başlarına Kadar Kocaeli Sancağı”, Yaynlanmamış Doktora Tezi. Ankara Üniversitesi Sosyal Bilimler Enstitüsü. Ankara.

HINZ, Walter (1990). İslâm'da Ölçü Sistemleri. Çeviren: Acar Sevim. İstanbul. Marmara Üniversitesi Yayınları. Edebiyat Fakültesi Basımevi.

İNALCIK, Halil (1959). "Osmanlılarda Raiyyet Rüsumu”. Belleten. Cilt. XXIII, Say1 92. Ss. 31-65.

İNALCIK, Halil (1993). “Köy, Köylü ve İmparatorluk”, Osmanlı İmparatorluğuToplum ve Ekonomi, ss. 1-14. İstanbul. Eren Yayıncılı.

İNALCIK, Halil (2000).Osmanlıİmparatorluğu'nun Ekonomik ve Sosyal Tarihi. Cilt 1: 1300-1600. 1. Baskı. Türkçeye Çeviren: Halil Berktay. İstanbul. Eren Yayıncılık.

İNBAŞI, Mehmet ( 2006 ). "XVIII. Yüzyılın İkinci Yarısında Çıldır Eyâleti ve İdarecileri”, Atatürk Üniversitesi Sosyal Bilimler Dergisi, Cilt: 7 - Sayı: 1, ss. 77-94.

KANKAVA, M. B. (2001).Kartul-Rusuli Leksikoni (Gürcüce-Rusça Sözlük). Mesame Gamotsema (Üçüncü Baskı). Tbilisi. Sakartvelos matsne.

Kartlis Tskhovreba (2008). İstoriya Gruzii. Baş Editör: Roin Metreveli. Tbilisi. İzdatelestvo Artanudzhi.

KETSKHOVELİ, Niko (1971). Morbis aragvi, aragviani. Tbilisi. Nakaduli.

KILIÇ, Ümit(2008). “Oltu'da Arslan Paşa Külliyesi”, Karadeniz Araştırmaları, Cilt: 5, Sayı: 17, Bahar 2008, s.113-131.

KIRZIOĞLU, M. Fahrettin(1992). Yukarı-Kür ve Çoruk Boyları'nda Kıpçaklar. İlk-Kıpçaklar (M.Ö VIII.- M.S. VI. Yy.). Son-Kıpçaklar $(1118,1195)$ ile OrtodoksKıpçak Atabekler Hükûmeti (1267-1578). Ahıska / Çıldır Eyâleti Tarihi'nden. Ankara. Türk Tarih Kurumu Basımevi.

KIRZIOĞLU, M. Fahrettin (1998). Osmanlılar'ın Kafkas-Ellerini Fethi (14511590), 2. Bask1, Ankara. TTK Basımevi.

KONUKÇU, Enver (1999). Ardahan Tarihi, T.C. Ardahan Valiliği Kültür Yayınları, No: 2, Ankara. Ajans-Türk Basım A.Ş.

KURT, Yılmaz (2005). Kars-1 Maraş (Kadirli) Sancağında Ekonomi. XIV. Türk Tarih Kongresi. Ankara: 9-13 Eylûl 2002. Kongreye Sunulan Bildiriler. II. Cilt II. Kısım. ss. 1901-910. Ankara. Türk Tarih Kurumu

LOMSADZE, Şota (1999). Meskheti i mesxi. Tbilisi.“Merani-3”.

MOSAKHLEOBİS SAKOVELTAO AĞTSERA 2014. Sakartvelos statistikis erovnuli samsakhuri (noemberi 2014). Tsakitxvis tariği: 7 noemberi, 2016.

MROVELİ, Leonti (1979). Jizn kartliyskikh tsarey. İzvleçenie svedeniy ob abkhazakh, narodakh Severnogo Kavkaza i Dagestana. Perevod s drevnegruzinskogo, predislovie i kommentarii G. V. Tsulaya. Otvetstvennıy redaktör G. S. Mamulia. Moskva. İzdatelstvo "Nauka".

NIKOLAİŞVILİ Dali, SARTANİA, Davit, UCMACURİZZE, Avtandil (2016). Vazis Kultura Samtskhe-Cavakhetshi. ss. 43-60. İvane Cavakhişvilis Sakhelobis Tbilisis Sakhelmtsipo Universiteti. İromata Krebuli. Sametsniero Konferensiis Masalebi. "Regionuli ganvitarebis perspektivebi: Samtskhe-Cavakheti. Tbilisi. 
PAKALIN, Mehmet Emin (1952). Osmanlı Tarih Deyimleri ve Terimleri Sözlüğü, II. XIII. Fasikül. İstanbul. Millî Eğitim Basımevi

PAMUK, Şevket (2007), Osmanlı-Türkiye İktisadi Tarihi 1500-1914, İstanbul. İletişim Yayınları.

PARLATIR, İsmail (2011). Osmanlı Türkçesi Sözlüğü. 4. Baskı. Ankara.Yargı Yayınları.

PRONELİ, A. (1991). Didebuli Mesheti, Marihi. Tbilisi. Redaktör: Sarcveladze Z.

SAHİLLİOĞLU, Halil (1991), “Avarız”, DİA, C.IV., İstanbul.

SAKARTVELOS MOSAKHLEOBIS 2002 TSLIS PIRVELI EROVNULI SAKOVELTAO AĞTSERİS ZİRITADİ ŞEDEGEBİ(2003). (Sakartvelos soplebis mosakhleoba). Tomi II. Tbilisi.

SAKARTVELOS PINANSTA SAMINISTRO(2016), Sakartvelos 2016 Tslis Biucetis Şesrulebis 6 tvis mimohilva, Tbilisi.

SAMKHARADZE, Tornike (2013). Samtskhe-Javakheis regionis reliepi da geodinamikuri protsesebi (Geodinamics process and relief region of Samtskhejavakheti). Samagistro şroma. İvane Cavakhişvilis Sakhelobis Tbilisis Sakhelmtsipo Universiteti Zust da Sabunebismetkvelo Metsnierebata pakultetis geograpiis mimartulebis geomorpologia-geoekologia, kartograpia-geoinpormatikis specialobis magistri. Tbilisi.

SAYDAM, Abdullah (1999). Osmanlı Medeniyeti Tarihi.Trabzon. Derya Kitabevi.

SELSKO-KHOZYAYSTVENNIY PEREPIS 1917 g.; Tiflisskaya guberniya: Akhaltsikhskiy uezd, Tiflis, s. 44-93.

SERTOĞLU, Midhat (1992), Sofyalı Ali Çavuş Kanunnâmesi, İstanbul. Marmara Üniversitesi Fen-Edebiyat Fakültesi Yayınları.

SOLAK, İbrahim (2008). Osmanlı Imparatorluğu Döneminde Anadolu'da Meyve ve Sebze Üretimi. Selçuk Üniversitesi Türkiyat Araştırmaları Dergisi(24), 217-251

SSDZK (1893). Svod Statistiçeskih Dannıh, İzvleçennıkh İz Posemeynıkh Spiskov 1886 g. o Naselenii Zakavkazskogo Kraya (Tiflisskaya, Bakinskaya, Erivanskaya i Yelizavetpolskaya Gubernii) (1893). s. 66-68. İzdan Zakavkazskim statistiçeskim komitetom,Tipografii İ. Martirosyantsa.Tiflis.

ŞAHIN, Harun(2013). "XVI-XVIII. Yüzyıllarda Osmanlı Mukâtaa Sisteminde Yönetim ve Örgütlenme", International Journal of Social Science. DOİ Number: http://dx.doi.org/ 10.9761/JASSS1534. Volume 6 Issue 6, p. 1019-1037.

ŞEMSEDDIN Sami: (2011). Kamus-i Türki (Latin Harfleriyle). I. Bask1, İstanbul.İdeal Kültür Yayınları.

ŞENGELİA, Nodar (2005). “1574 Tarihli "Defter-i Mufassal Vilâyet-i Gürcistân”. XIV. Türk Tarih Kongresi. Ankara: 9-13 Eylûl 2002. Kongreye Sunulan Bildiriler. II. Cilt II. Kısım. ss. 1499-1506. Ankara. Türk Tarih Kurumu.

TAŞKIN, Ünal (2007). 1540 (H. 947) “Tarihli Kanunnamelere Göre Musul, Amid ve Erzurum Sancaklarında Ziraî Gelirlerin Mukayeseli Tahlili”. Turkish Studies/Türkoloji Araştırmaları, 2/2 Spring 2007, s. 632-653.

TAŞTEMIR, Mehmet (1999). XVI. Yüzyılda Adıyaman (Behisni, Hısn-ı Mansur, Gerger, Kâhta) Sosyal ve İktisadî Tarihi. Ankara. Türk Tarih Kurumu Basımevi. 
ÜNAL, Mehmet Ali (1989). XVI. Yüzyılda Harput Sancağı (1518-1566),Ankara. Türk Tarih Kurumu Basımevi.

ÜNAL, Mehmet Ali (1999). XVI. Yüzyılda Çemişgezek Sancağı. Ankara. Türk Tarih Kurumu Basımevi.

VEYDENBAUM, E. (1878). Svyaşennıye roşi i derevnya u Kavkazskix narodov. İzv. KİRGO, V, № 3.

YÖRÜK, Doğan (2007). XVI. Yüzyılın İkinci Yarısında Osmanlı İmparatorluğu'nda Yaşayan Gayrimüslimlerin Nüfusu, Selçuk Üniversitesi Sosyal Bilimler Enstitüsü Dergisi, say1, 17. 625-652.

YÖRÜK, Doğan (2010). “15 ve 16. Yüzyıllarda Ereğli’de Yapılan Ziraî Faaliyetler”, II. Ulusal Konya Ereğli Kemal Akman Meslek Yüksekokulu Tebliğ Günleri, Sayı 2, 2010, No:1-622 /ss. 1-14/

YÖRÜK, Doğan (2002). XVI. Yüzyılda Aksaray Sancağı. Doktora Tezi. Selçuk Üniversitesi Sosyal Bilimler Enstitüsü Tarih Anabilim Dalı Yeniçă̆ Tarih Bilm Dalı. Konya.

ZİSSERMAN, [Karl Lvoviç]: (1870). Sbornik Materialov Dlya Opisaniya Tiflisskoy Gubernii, izdavaemıy pri kanselyarii Tiflisskogo gubernatora pod redaksiyu pravitelya onoy K. L. Zissermana, Tom I, Vipusk I, Tiflis, Tipografiya Dubelira.

\section{SÖZLÜ KAYNAKLAR}

Ak, VALİDA -1983 Gürcistan Doğumlu.

BEKADZE, SHAKHMURAD-1963 Azerbaycan Doğumlu. Yüksek Mühendis.

KESKİN, HAYRETTíN Müti oğlu- 1944. Gürcistan, Akhaltsikhe Belediyesi Sakuneti Köyü Doğumlu, Şu an Bursa'da ikamet etmektedir.

\section{INTERNET KAYNAKLARI}

URL-1. Cemşit Halit (2016), Vatan ziyareti. Azğur, Sakunet , Agara. http://www.ajansahiska.com/ makale/vatan-ziyareti-azgur-sakunet-agara_m49.html. Erişim Tarihi: 10 Mart 2017.

URL-2. Sakuneti Köyünün Görüntüsü. https://e.mail.ru/attachment/1489760597 0000000394/0;1. Erişim Taihi: 10 Mart 2017

URL-3.

v_akhalcikhskom_municipalitete_okolo_sela_sakuneti_stroitsja_novaja_ehlektropodstancij a__ moshhnostju_v_1000_megavatt/,http://rus.akhaltskha.net/news/v_akhalcikhskom municiplitete_okolo_sela_sakuneti_stroitsja_novaja_ehlektropodstancija_moshhnostju_v_1 000_megavatt/2011-10-27-1226. Erişim Tarihi: 10 Şubat 2017).

URL-4. Esida. http://www.esida.ge/index.php?option=com_esida\&view=school \&Itemid=0\&sid=1550\&lang=ka (Erişim Tarihi: 10 Mart 2017).

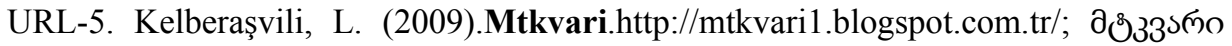

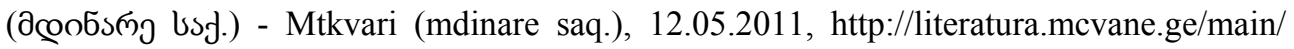
gegographic/ocean_sea_river/3712-bbbbbbb-bbbbbbb-bbb-mtkvari-mdinare-saq.html, Erişim Tarihi: $28.0 \overline{2} .20 \overline{1} 7$ 
URL-6. Hidrografia. http://akhaltsikhe.ge/portal/alias_Akhaltsikhe/tabid_3660/ default.aspx. Erişim Tarihi: 10.03.2017.

URL-7. Yessentuki'den Mektup (23.03.1989). http://www.nplg.gov.ge/gsdl/cgibin/library.exe? e=d-00000-00---off-0civil2--00-1----0-10-0---0---0prompt-10---4-------0-11-10-ka-50---20-about---00-3-1-00-0-0-01-1-0utfZz-8-

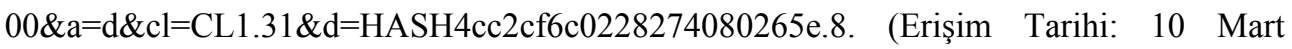
2017).

URL-8. Ra mdgomareoba Samtskhe-Cavakhetşi arsebul meçetebşi -nagemobebi gadaudebel restavrasias saçiroebs. Moambe. 1 TV.GE. Rezo Anğuladze'nin Haberi. https://www.youtube.com/watch?v=ErYYFMmslUY. Erişim Tarihi: 10.03.2017

URL-9. Foto Sakuneti. https://www.alltravels.com/georgia/akhaltsikhis/agara/photos/ current-photo-83407869. Erişim Tarihi: 10.03.2017

URL-10. Saxalxo_Gazeti_Suratebiani_Damateba_1913_N178-6.jpg, http://www. dspace.nplg.gov.ge/ handle/ 1234/160159. Erişim Tarihi: $\overline{10} .03 . \overline{2} 017$

URL-11. Kartuli islamuri kulturuli memkvidreoba. https://www.facebook. com/GeorgianJame/photos/

ms.c.eJxFz9sNBDEIA8COTjxN6L x04Li ;I6MAYW0iSggnsfqpxfa0Qoh9CbigskkEgTb hBK2I9lhZSUWxwk9ieBal 1QJtwX̄'2OExHcW1vqfL69gtxY7QTRjBJoFDyIUkYOF _6 51fR8QdyZhvXfRBOw48CN $\sim$ 12gChvhHrB9gReYkB6wup05H9B1TVVOo .bps.a.16092 $00159369161.1073741879 .147 \overline{4} 982656124246 / 1609200209369156 /$ type $=3 \&$ theater.

Erişim Tarihi: 10.03.2017

URL-12. Kültür Mirası Anıtları, Kulturis Ministri Meçetebs Kulturuli Memkvidreobis Dzeglis Statüsü Mianiça,http://www.ick.ge/rubrics/culture/10384-2012-0331-17-16-54.html, Erişim Tarihi: 23.04.2014.

URL-13. Natia Gogolaşvili (20.01.2016). Kalbatons Sakunetis meçetis movlapatronoba aukrdzalis, http://humanrights.ge/blue/index.php?a=text\&pid=18609\&lang=geo. Erişim Tarihi: 08 Mayıs 2017.

URL-14. Upatrono salotsavebi "Radio Tavisupleba", Noemberi (Kasım) 19, 2016. Erişim Tarihi: 23.04.2017.

URL-15. Gvarebi Samtskhe-Javakhetşi, Kolaşi, Artaanşi, Taosa da Borcomis Kheobaşi (Samtskhe-Javakheti, Göle, Ardahan, Tao ve Borcomi Deresi Soyadları. http:/geogen.ge/ge/treasurege/84/4305 / . Erişim Tarih: 10 Mart 2017.

URL-16. Gvarebi Samtskhe-Javakhetşi, Kolaşi, Artaanşi, Taosa da Borcomis Kheobaşi (Samtskhe-Javakheti, Göle, Ardahan, Tao ve Borcomi Deresi Soyadları http://geogen.ge/ge/treasurege/84/4305/. Erişim Tarih: 10 Mart 2017.

URL-17. Gvarebi Samtskhe-Javakhetşi, Kolaşi, Artaanşi, Taosa da Borcomis Kheobaşi (Samtskhe-Javakheti, Göle, Ardahan, Tao ve Borcomi Deresi Soyadları http://geogen.ge/ge/treasurege/84/4311/. Erişim Tarih: 10 Mart 2017.

URL-18. Gvarebi Samtskhe-Javakhetşi, Kolaşi, Artaanşi, Taosa da Borcomis Kheobaşi (Samtskhe-Javakheti, Göle, Ardahan, Tao ve Borcomi Deresi Soyadları http://geogen.ge/ge/treasurege/84/4311/. Erişim Tarih: 10 Mart 2017. 
URL-19. Gvarebi Samtskhe-Javakhetşi, Kolaşi, Artaanşi, Taosa da Borcomis Kheobaşi (Samtskhe-Javakheti, Göle, Ardahan, Tao ve Borcomi Deresi Soyadları http://geogen.ge/ge/treasurege/84/4313/. Erişim Tarih: 10 Mart 2017.

URL-20. Gvarebi Samtskhe-Javakhetşi, Kolaşi, Artaanşi, Taosa da Borcomis Kheobaşi (Samtskhe-Javakheti, Göle, Ardahan, Tao ve Borcomi Deresi Soyadları http://geogen.ge/ge/treasurege/84/4325/. Erişim Tarih: 10 Mart 2017.

URL-21: Meputkreoba (Arıcılık) http://akhaltsikhe.ge/portal/alias_Akhaltsikhe/ tabid_3665/default.aspx. Erişim Tarih: 10 Mart 2017

URL-22. (13.10.2015). Vaşlis bağis gaşeneba Meskhetşi da ramodenime cişis dakhasiateba. http://agrokavkaz.ge/dargebi/mebageoba/vashlis-baghis-gasheneba meskhet hshi-da-ramodenime-jishis-dakhasiatheba.html. Erişim Tarih: 10 Mart 2017

URL-23 (18.10.2016). MUCİİ, Kristine. Meçeti arağiarebuli istoriit. http://liberali.ge/blogs/view/25353/ mecheti-araghiarebuli-istoriit. Erişim Tarih: 10 Mart 2017.

URL-24. Merva Kindiyev'i, http://www.nplg.gov.ge/gsdl/cgi-bin/library.exe?e=d00000-00---off-0civil2--00-1----0-10-0---0---0prompt-10---4-------0-11--10-ka-50---20about---00-3-1-00-0-0-01-1-0utfZz-8-

$00 \& \mathrm{a}=\mathrm{d} \& \mathrm{cl}=\mathrm{CL} 1.31 \& \mathrm{~d}=$ HASH4cc2 $\mathrm{cf6c0228274080265e.8.} \mathrm{Erişim} \mathrm{Tarih:} 10$ Mart 2017.

URL-25. Obraşeniye Gruzii. Glava I. http://www.vostlit.info/Texts/rus5/ Obrasenie/frametext.htm, Erişim Tarihi: 29 Mart 2017.

URL-26. Sarkineti (Dmanisis), http://saunje.ge/index.php?id=1058\&lang=ru, Erişim Tarihi: 29 Mart 2017.

URL-27. Mosakhleobis ritskhovanoba administratsiuli-teritoriuli erteulebis da skesis mikhedvit. http://www.geostat.ge/index.php?action=page\&p_id=2152\&lang=geo. Erişim Tarihi: 29 Mart 2017.

EK 1: 1003 / 1595 Tarihli TTD'nin 52. ve Cikia'nın 1947 Yllında Osmanlıca Yayınladığı Kitabın 91-92. Sayfalarındakı Sakuneti Köyü ile İlgili Bilgilerin Günümüz Türkçesindeki Transkripti. 


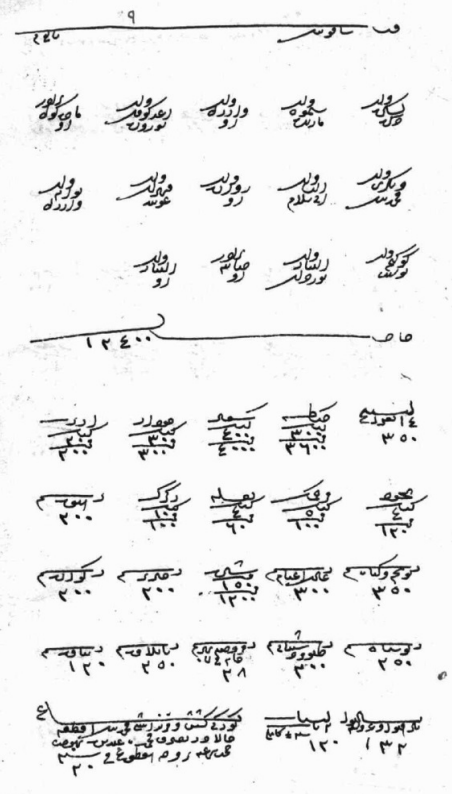

Kaynak: TTD, 1003 (1595): 52 


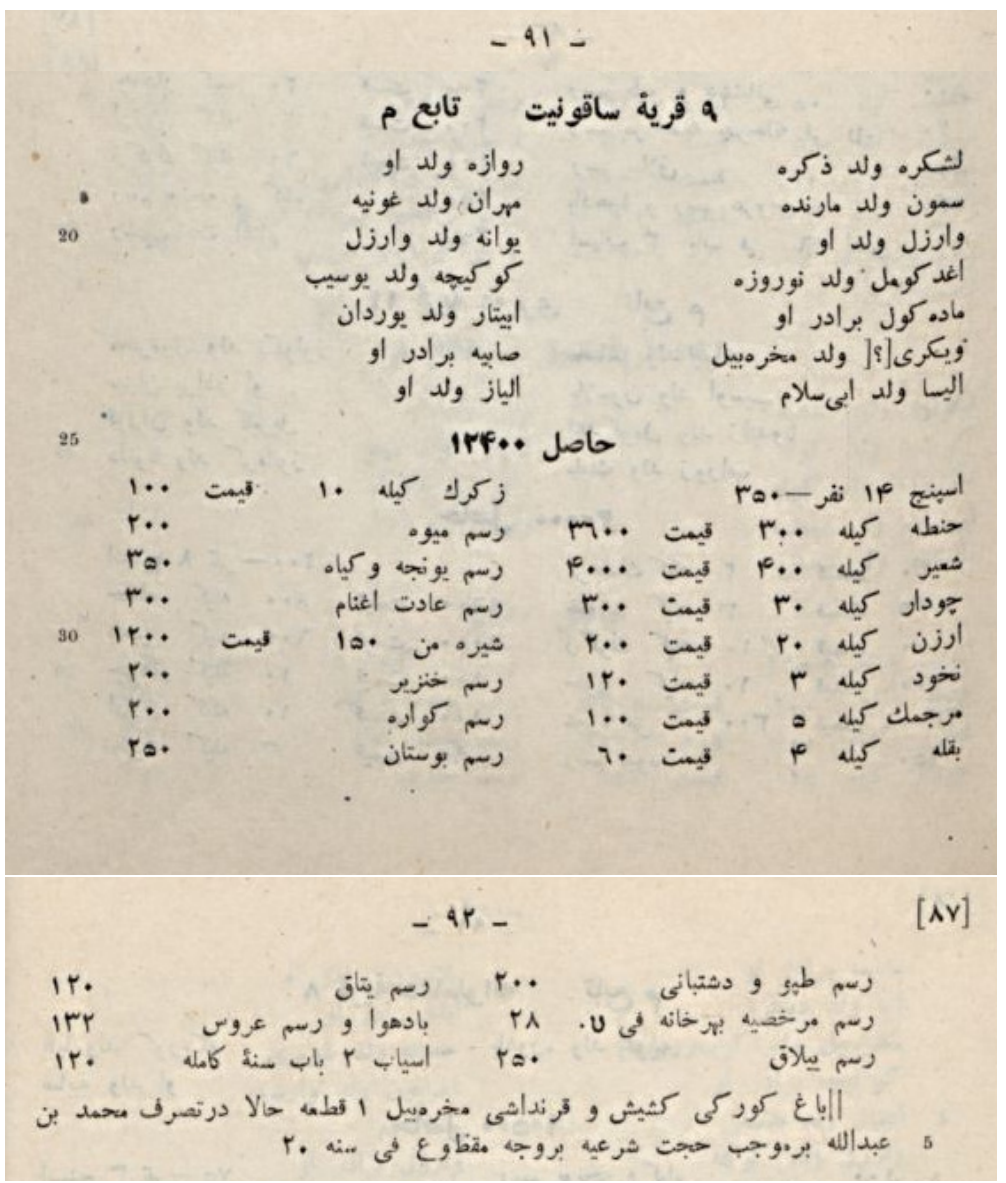

Kaynak: Cikia, 1947: 91-92

9. Karye-i Sakunet tâbi`-i m. [mezbûr] TTD 52; Cikia, 1947: 91-92)

\begin{tabular}{|l|l|l|l|}
\hline Leşkere veled-i Zakira & Madagülbirâder-i o & Mihran veled-i Ğvinia & Sabiya birâder-i o \\
\hline Simon veled-i Marinda & Vikri veled-i Mehrebil & İvane veled-i Varzel & İlyazveled-i o \\
\hline Varzel veled-i o & Elisa veled-i Abesalom & Gogiça veled-i Yusib & \\
\hline Ağdgomel veled-i Novruza & Revaza veled-i o & Abitar veled-i Yordan & \\
\hline
\end{tabular}

Hâs1l 12.400

\begin{tabular}{|l|c|c|l|c|}
\hline \multicolumn{1}{|c|}{ [Vergi Kalemleri] } & Kile & Kiymet [akçe] & \multicolumn{1}{|c|}{ [Vergi Kalemleri] } & $\begin{array}{c}\text { Kiymet } \\
\text { [akçe] }\end{array}$ \\
\hline İspenç, 14nefer & & 350 & Resm-i âdet-i ağnâm & 300 \\
\hline Hınta & 300 & 3600 & Şıra,150 men & 1200 \\
\hline Şa'ir & 400 & 4000 & Resm-i hınzır & 200 \\
\hline
\end{tabular}


KARADENIZ, 2017; (34)

\begin{tabular}{|l|c|c|l|c|}
\hline Çavdar & 30 & 300 & Resm-i kevvâre & 200 \\
\hline Erzen & 20 & 200 & Resm-i bostân & 250 \\
\hline Nohut & $4^{12}$ & 120 & Resm-i tapû ve deştbâni & 200 \\
\hline Mercimek & 5 & 100 & $\begin{array}{l}\text { Resm-i murahhasiye be her } \\
\text { hâne-i fi 2 }\end{array}$ & 28 \\
\hline Bakla & 4 & 60 & Resm-i yaylak & 250 \\
\hline Zeğrek & 10 & 100 & Resm-i yatak & 120 \\
\hline Resm-i meyve & & 200 & Bâd-i havâ ve resm-i arûs & 132 \\
\hline Resm-i yonca ve giyâh & & 350 & $\begin{array}{l}\text { Asiyâb, 2 bâb, sene-i } \\
\text { kamila }\end{array}$ & 120 \\
\hline
\end{tabular}

Bağ-i Giorgi Keşiş ve karındaşı Mehrebil bir kıt'a hala der tasarruf-1 Mehmed bin Abdullah ber mûceb-i hüccet-i şer'iyye ber vech-i maktu'a fi sene 20 .

Kaynak: TTD, 1003 / 1595: 52; Cikia, 1947: 91: 92.

12 Orjinalda 4, Cikia'da 3 rakamı matbaa hatası olarak yazılmıştır. Zira metnin gürcüce tercümesinde orijinalda olduğu gibi 4 yazılmıştır (Cikia, 1941: 94).

${ }^{13}$ Kamila-Tam Y1l 